\title{
A Complex Network Analysis of Global Tourism Flows
}

\author{
Sebastián Lozano | Ester Gutiérrez \\ ARTÍCULO PUBLICADO EN \\ INTERNATIONAL JOURNAL OF TOURISM RESEARCH (2018) \\ doi: $10.1002 /$ jtr. 2208
}

\begin{abstract}
In this paper, the global tourism network (GTN) is studied in order to gain insight about its structure and the interactions between source and destination markets. To concentrate on the main source and destination markets for each country only its top $\mathrm{k}$ inbound and outbound flows are considered. The distribution of these most important ties in international tourism seems to be scale-free, with some occurrence of reciprocity, large transitivity and high degree centralization. The GTN shows a clustered structure determined by geographical as well as trade and cultural factors. Each major global and regional power seems to have a certain tourism sphere of influence. The network has a small world character and a high degree of geographic homophily, with more links within continents than between continents. Exponential random graph models (ERGM) have been fit to explain the observed global structure of the network based on its local interactions and a number of significant motifs have been identified. The picture that results is a global tourism network that emerges from superimposed local processes in which tourism flows between countries are determined from multiple independent individual decisions made at the local level. This insight that global tourism patterns are driven by local processes is a major contribution of this research and can help develop strategic plans and cooperation partnerships at the national and regional levels, involving private and public stakeholders and targeting specific source and destination markets. The indicators computed using network analysis of global tourism flows can also be used to complement and enrich the information provided by current tourism statistics.
\end{abstract}

Keywords: top inbound/outbound flows; scale-free; small-world; clustered structure; geographic homophily; emergent structure 


\section{Introduction}

Tourism is one of the fastest growing sectors of international services trade, having become a crucial factor of economic and socio-cultural progress through the generation of new enterprises, employment growth, tourism revenues and investments in infrastructure. On the other hand, the industry faces a number of challenges, among them its significant environmental impact, the emergence of the "sharing economy", new patterns in leisure travel and new market niches (e.g. millennials).

International tourist arrivals worldwide reached 1,235 million in 2016, bringing the total value of tourism receipts to 1,220 billion US\$ and providing 380 million jobs for the global workforce (UNWTO, 2017; WTTC, 2017). Moreover, this past growth pattern in international tourist arrivals is expected to continue, with an average annual growth rate of $3.3 \%$ between 2010 and 2030 (UNWTO, 2011).

Figure 1 shows regional past and forecasted trends of international tourist arrivals. Over time, Europe has become the world's largest destination region, increasing from 261 million arrivals (60\% market share) in 1990 to 607.7 million arrivals (51\% of global total) in 2015 and it is expected to reach 744 million (41\% of global total) in 2030, with the Southern/Mediterranean Europe as the preferred subregion tourist destination in first place and Western Europe in second place. The second most visited region is Asia and the Pacific going from 55.9 million (13\% of global total) in 1990 to 279.2 million (24\% of global total) in 2015, reaching more than 500 million arrivals in 2030. During this period the largest number of tourist arrivals is reached in the subregion of North-East Asia. The other tourist regions are the Americas (around 17\% of global total), the Middle-East (around 6\% of global total) and Africa (around $5 \%$ of global total). Of course, war and social unrest may hold back tourism growth in the affected regions.

\section{Figure 1}

Tourism has a direct impact on the wider economy with a remarkable effect on Gross Domestic Product (GDP) and employment. Table 1 lists the top 10 destination countries in terms of the largest absolute and relative contribution of tourism to GDP in 2016 (WTTC, 2017). USA, China and Germany are the world's top 3 countries in tourism's total contribution to GDP. On the other hand, the tourism sector represents more than $40 \%$ of total GDP for some small-island countries and emerging tourist destinations. 
In the era of smart tourism, characterized by a massive amount of data generated by touristic activities, advanced data analysis tools to process and make sense of this information are required (Gretzel et al. 2015). Network analysis (NA) is a relatively new mathematical tool that allows characterizing the structure of complex real-world networks, identifying communities within them, measuring their robustness and, in general, linking their structural and functional characteristics (Newman 2003). The range of NA applications is very broad and covers all fields (see, e.g., da Fontoura Costa et al. 2011). Thus, for example, it has been applied to study the global airport network (e.g. Guimerà et al. 2005), airlines alliances (e.g. Lordan et al. 2015), international trade (e.g. Serrano and Boguná 2003), etc. In the next section, existing NA applications to tourism are reviewed and classified.

In this paper, the global tourism network (GTN) is studied using NA to assess the structure and interrelationships. The methods used for analysis of networks are different from the statistical methods which are conditional upon independent units of analysis. NA can contribute to a better understanding of the international tourism phenomenon and the identification of the roles performed by the different countries and regions. Understanding the drivers of international tourist flows is important as visitor's nationality is one of the factors influencing expenditure levels in destination countries, expenditure that contributes to promote its economic development. In this study and to concentrate on the main source and destination markets for each country only its top $\mathrm{k}$ inbound and outbound flows are considered. This gives rise to a less dense network that conserves the information about the key tourism flows. Besides, this paper introduces a new approach in the examination of worldwide network tourism destinations based on Exponential Random Graph Models (ERGM) that infer the characteristics and structure of the network based on its ability to model relational interdependence. The characterization of the GTN shows a scale-free degree distribution, with reciprocal and transitive links, high degree centralization and a clustered structure highly influenced by geographical and cultural proximity and trade. The structure of the paper is the following. Section 2 carries out a literature review. Section 3 presents and discusses the structure of the GTN. Section 4 summarizes and concludes.

\section{Literature review}

There are several surveys of NA applications to tourism (Baggio et al. 2010, Casanueva et al. 2016, Baggio 2017). As shown in Table 2, the largest group of applications (and the most traditional) corresponds to those that study tourism destination networks. The main aim of 
those studies is to analyse and visualize the relationships between the multiple stakeholders in a tourism destination (hotels, travel agencies, restaurants and bars, transportation services, destination management organization and other public organizations, etc.), studying the density and clustering of the network relationships and identifying those stakeholders that play a central role. Knowledge transfer between destination stakeholders, community structure, resilience, brokerage possibilities, assortativity, etc. have also been the objects of this type of research. In most cases the information is obtained through documentation, surveys and personal interviews and refers to "real-world" relationships of various kinds (commercial agreements, partnerships, co-memberships in associations, co-ownership, etc.). Some studies, however, use a more automated way of obtaining the information using the links between the Internet websites of the organizations involved. In this case the network reflects the virtual relationships between them, which are hypothesised to mimic those of the real world. Actually, both the real world and virtual connection between the organizations are coupled and co-evolve with time (Baggio and Del Chiappa 2014).

Another topic that has been extensively studied is that of mobility patterns and itinerancy networks. These are weighted directed networks whose links indicate the frequency with which a tourist visits one city/attraction after another (see references in Table 2). A similar group of papers are those that study the links between cities, villages, etc. based on spatial proximity or even tourist flows but generating, in any case, an undirected network (see references in Table 2).

Another category of NA applications to tourism whose number is growing involves social media and internet sources. These applications are different to the ones mentioned above of stakeholders networks based on web links. Here we refer to capturing and processing the information that visitors profusely and voluntarily post on-line. This includes, for example, geo-located Twitter messages (e.g. Hawelka et al. 2014, Provenzano et al. 2018), specialized blogs (e.g. Chung et al. 2017) or geo-tagged photos (e.g. Junker et al. 2017). This category also includes analyzing destination electronic word of mouth (eWOM) (e.g. Luo and Zhong 2015, Williams et al. 2017) as well as navigation paths in on-line trip planning (Li et al. 2015). It is foreseeable that the number of this type of approaches will increase even more in the future as the perceived potential benefits of using big data tools to process are immense.

There are also some papers that study the dynamics of tourism systems using the NA of time series (overnight stays, inbound tourist flows, etc.). In this type of applications the 
nodes of the network to be analyzed correspond to time periods (e.g. yearly data) and the links are determined using the natural or horizontal visibility algorithm. Analysing the degree distribution allows assessing the onset of chaos and community detection allows identification of turning points in the dynamics o the system (e.g. Sainaghi and Baggio 2017).

Another interesting category corresponds to studies that investigate the relationship between tourism and human mobility in general. Thus, for example, the extent to which existing migrant stocks can explain Visiting Friends and Relatives (VFR) travel has been studied in Provenzano and Baggio (2017). Belyi et al. (2017) uses a different perspective, considering tourism travel (inferred from Flickr and Twitter social media communities) as representing short-term human mobility patterns as opposed to migration which represents a long term one.

There are also some NA applications to tourism that are more difficult to categorize. Thus, the nodes in the network studied in Park et al. (2010) are travel styles and the weights of the arcs are the number of co-occurrences of two travel styles in the recent (or planned) trips indicated by a number of survey respondents. Karl and Reintinger (2017) study three types of network built from a survey of travellers' past, current and future/hypothetical destination choices while Tsiotas (2017) builds port and prefecture-level maritime networks (in L-space representation) with link weights proportional to spatial distance and uses some NA measures, together with socioeconomic variables, as predictors of a number of tourism variables. Taczanowska et al. (2017) use NA to study mobility data of backcountry skiers captured using Global Positioning System (GPS) tracking, comparing the structural network of skiing zones with the functional network corresponding to the actual use of the area by skiers. Hernández and González-Martel (2017) study how the observed bipartite lodgingservice networks can result from a growth process that yields degree distributions which, depending on a parameter that controls the probability of preferential attachment, leads to a shifted power law in one extreme case or an exponential distribution in the other. Another original NA application to tourism is presented in Khalilzadeh (2018), who applies ERGM to the bipartite network between destinations and attitudinal values.

Finally, there are a few papers that are most relevant for this research, as they deal with national and GTN flows. Thus, Miguéns and Mendes (2008) build a weighted directed network whose 208 nodes represent countries and edges represent tourist flows in the year 2004. They study the distribution of weights, in- and out-degree and in- and out-strength. They also study the relationship between strength and degree as well as weighted and unweighted degree-degree correlations. González-Díaz et al. (2015) build four weighted 
directed networks whose nodes are the 17 Spanish autonomous regions and the edges represent tourism flows in hotel and non-hotel accommodations for the years 2001 and 2012, respectively. In- and out-degrees, in- and out-strength, in- and out-closeness, weighted and un-weighted random-walk betweenness centrality, Herfindahl strength-concentration index, etc. are all computed.

\section{Top outbound and inbound GTN: Results and Discussion}

Data on the global tourism flows between the 214 countries in the world are available from the World Tourism Organization (WTO) database. Specifically, the data used in this study correspond to "Trips abroad by resident visitors to countries of destination" statistics (UNWTO, 2016a) and "Arrivals of non-resident tourists at national borders (UNWTO, 2016b), by country of residence" statistics for the year 2013. Since the complete GTN is almost fully connected, a way of filtering the edges so as to obtain a simplified version with the most relevant information must be devised. One way to do that would be to establish a threshold so that all edges with weights below a certain value would be ignored and edges above the threshold would be kept. However, it is difficult to select a value of such an absolute threshold that suits both large and small countries and, in any case, it would be arbitrary. Using a relative threshold (i.e. a percentage of the total tourism flows of the destination country) or Pareto Analysis (so that only the links with the largest weight representing, for example, $80 \%$ of the total flows are kept) would not guarantee the connectivity of all nodes of the network. Instead of doing that, in this paper, we apply the procedure suggested in Zhou et al. (2016) for international trade, which consists of keeping just the top-ranked $\mathrm{k}$ inbound and outbound edges of each country. This significantly reduces the number of edges while guaranteeing that all countries are connected and equally represented in the network. Actually, two different networks are built: one for inbound tourism flows and the other for outbound tourism flows. In the top $\mathrm{k}$ inbound tourism network, each country has $\mathrm{k}$ incoming edges, which correspond to its top $\mathrm{k}$ sources of tourism flows. Similarly, in the top $\mathrm{k}$ outbound tourism network each country has $\mathrm{k}$ outgoing edges, which correspond to the top $\mathrm{k}$ destinations of its own tourism flows. Figures 2 and 3 show the top 1 outbound and top 1 inbound networks, respectively. The node sizes correspond to their in-strengths and out-strengths, respectively.

Figure 2 shows the top 1, 2 and 3 outbound GTN visualized using NetDraw (within the UCINET 6.0 Package, Borgatti et al. 2002). Although in each of them the number of outgoing arcs is fixed, the number of incoming arcs (i.e. the in-degree) is not uniform. In the 
top 1 outbound network, several countries, namely USA, South Africa, Ukraine, Malaysia, Thailand, Spain, France and Greece, already stand out as first receptors of tourism flows from a number of countries. The picture shows that traveller motivations are fragmented and diverse. USA is the top 1 preferred tourist destination in the world by the nationality; in particular, the majority of the nationalities that USA receives are from Latin American and African countries. South Africa and Ukraine are the first destination chosen by most of African countries and Eastern Europe countries, respectively. Note that the impact of the Crimean crisis in late 2013 and 2014 does not seem to have severely undermined Ukraine's relationship with its neighbours in the region yet. Besides, Malaysia and Thailand climbed the first place each for tourists from Asia Pacific and Middle East regions. The presence of two top country destinations from Asia Pacific region, Malaysia and Thailand, is the result of the fast growth of their tourism industry in recent years. Finally, Spain, France and Greece are mature and consolidated tourist destinations and are chosen by most European nationalities. It can be noted that traditional Middle-East top destinations, such as Egypt and Tunisia, cannot be currently included among the favourite tourism destinations due to the persisting consequences of the political turmoil initiated in 2010 Arab Spring.

The aforementioned countries keep on being central in the top 2 and top 3 outbound networks, although those networks are already denser and more complex. Note that in the top1 outbound there are several unconnected components (such as the one grouping most European countries or another grouping most African countries), while this does not occur for the top 2 and 3 outbound GTN.

Figure 2 ==========================

As regards the top 1, 2 and 3 inbound GTN, they are shown in Figure 3. These networks are less dense because there were some countries for which the inbound tourism data were not available in the WTO database. Hence, in that sense, the inbound GTN are less complete; nevertheless, they still provide a very interesting picture of global tourism flows. Thus, some of the more central countries (such as the USA, France and South Africa) were also central in the top outbound GTN but there are other countries (such as the UK, Germany, Russia, Canada and China) which were not as important as tourism receptors but are important as tourism sources, as they are among the top three source markets for a number of countries. Note, however, the still modest weight of China as main international tourism source, something which is expected to change in the future, as its population increasingly has the resources and the willingness to make more journeys abroad. 
Table 3 shows some global measures of the different top outbound and inbound GTN. As expected, the number of ties, and hence the density, increases with the number of major flows from/to each country considered and so does the average strength. As the size of the largest network component increases, so does the diameter and average geodesic distance. The GTN seems, however, to be a small world. The average degree in the case of the top inbound GTN is lower than it should be and that is because for some countries there were no inbound flows data in the WTO database. That is reflected also in the lower number of ties (and lower density) of the top inbound with respect to the top outbound GTN. The high degree of centralization exhibited by the top outbound GTN is remarkable. The lower degree of centralization in the case of the top inbound GTN may be affected by the missing flows data. It is also interesting to note the relatively high degree of reciprocity, especially in the case of the top inbound GTN. The GTN, especially the top 3 outbound and inbound GTN, also exhibit a relatively high degree of transitivity, meaning that often two countries that share their main target or source markets have also strong tourism flows between them.

It can also be observed that in each top outbound GTN there are a few cases of reciprocal arcs. In particular, for the top 3 outbound GTN, there are 22 cases of reciprocated dyadic relationships: France and Greece, France and Spain, France and the USA, Canada and the USA, Mexico and the USA, Indonesia and Malaysia, Malaysia and Thailand, Thailand and Cambodia, Thailand and Hong Kong, Hong Kong and the Philippines, Peru and Brazil, Peru and Colombia, South Africa and Botswana, South Africa and Mauritius, the Dominican Republic and Haiti, Dominica and Guadeloupe, Barbados and Santa Lucia, French Guiana and Martinique, Benin and Mali, Ethiopia and Uganda, New Caledonia and Vanuatu and New Caledonia and French Polynesia. Note the strong geographical (and in some cases also cultural) proximity component of these mutual relationships that in most cases implies, relative low travelling cost. In addition, reciprocal outbound tourism connections can play an important role in reinforcing bilateral relationships of every kind (cultural, trade, foreign direct investment, etc) as well as promoting the speed of information and innovation diffusion and enhancing the overall efficiency of the GTN.

There are also reciprocal ties in the top inbound GTN. Actually, in the top 3 inbound GTN there are 44 cases of reciprocated dyadic relationships of which only two (the USA and Canada and the USA and Mexico) also occurred in the top outbound GTN. However, it still 
occurs that almost all these reciprocal relationships are governed by geographical (as well as ethnic/cultural/trade) proximity, i.e., France and the UK, the UK and the USA, Russia and Ukraine, Argentina and Brazil, Argentina and Chile, Argentina and Uruguay, Brazil and Paraguay, Bolivia and Chile, Algeria and Tunisia, Azerbaijan and Georgia, Bulgaria and Romania, Hungary and Romania, Moldova and Romania, Moldova and Ukraine, Indonesia and Singapore, Malaysia and Singapore, Japan and Korea, Japan and Taiwan, Saudi Arabia and Jordan, Saudi Arabia and Kuwait, Iran and Iraq, Tajikistan and Uzbekistan, Kazakhstan and Uzbekistan, Kazakhstan and Kyrgyzstan, Kazakhstan and Russia, etc. Moreover, unlike in the top 3 outbound GTN, in the top 3 inbound GTN there are two cases of cliques involving three countries. One is El Salvador, Guatemala and Honduras and the other is China, Hong Kong and Taiwan. The cliques displayed on the network indicate opportunities for reaching agreements and concerted action plans between the corresponding countries. The existing Central America Border Agreement that harmonises and establishes the free movement across borders and the recent Agreement on Further Enhancement of Tourism Cooperation between China and Hong Kong to jointly develop Maritime Silk Road tourism products are prime example of this.

As regards the distribution of the in-degree and in-strength of the top $\mathrm{k}$ outbound networks, they seem to follow a Power Law distribution that can be estimated using the method in Clauset et al. (2009). The same happens with the out-degree and out-strength of the top $\mathrm{k}$ inbound networks thus indicating that the degrees and strength distributions of top $\mathrm{k}$ outbound and top $\mathrm{k}$ inbound networks are highly right-skewed. Table 4 shows the corresponding exponents, the threshold $\mathrm{x}_{\min }$ above which the power-law distribution holds and the goodness-of-fit based on the Kolmogorov-Smirnov (KS) statistic. It can be seen that the in- and out-degree distributions have power law exponents between 2 and 3 while the exponents are lower than 2 for the in- and out-strength. The results leverage the assertion of Ulubasoglu and Hazari (2004) that when the power-law distribution holds true, then estimating tourist arrivals does not need to consider the principles of comparative advantage or price competitiveness and may be estimated by the destination's rank.

PageRank (Brin and Page 1998) is a common way of measuring centrality (i.e. relative "importance") in this type of weighted directed networks. In the outbound tourism network PageRank index assigns to each country a value that is proportional to the relative frequency with which a visitor travelling around the globe randomly following the different network 
arcs (with a probability proportional to their respective weights) would visit that country. Table 5 shows the 20 countries with the highest PageRank indexes for the different top $\mathrm{k}$ inbound and outbound networks. Countries that appear for all three values of $\mathrm{k}$ are shown in bold. In the outbound tourism network PageRank assigns a high relative importance to USA, Mexico, South Africa, Thailand, Botswana, Malaysia, France, Spain, Ukraine, Israel, Mauritius, Hong Kong, Benin, Greece, Ethiopia and Philippines. For the inbound tourism network the high PageRank countries are USA, Canada, China, Hong Kong, Germany, Argentina, France, South Africa, Russian Federation, Ukraine, and Uzbekistan. From that it can be noted the central position that USA and France enjoy as main players in both global outbound and inbound tourism. The relevance of South Africa as the top popular outbound/inbound tourism destination within the African continent, may have been enhanced by the 2013 Cup of African Nations, which has not only benefited South Africa's tourism, but also other African destinations as a whole, as visitors to this mega sporting event frequently travel to other countries in the region as well. The Spearman rank order correlations between the different top $\mathrm{k}$ inbound and between the different top $\mathrm{k}$ outbound GTN as well as between the two types of networks are significant at the 0.01 level and very high (ranging from 0.777 to 0.968$)$.

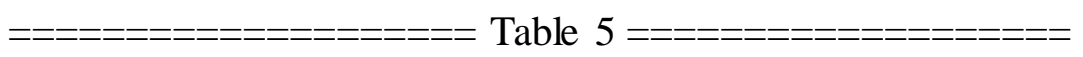

Tables 6 and 7 show the top 20 countries with the highest degree, strength and betweenness of the top 3 outbound and inbound GTN respectively among 214 countries. For the top outbound GTN the in-degree and in-strength measure the importance of a country as a destination of major tourism flows, out-strength measures its size as a tourism source. On the other hand, for the top inbound GTN, out-degree and out-strength measure the importance of a country as a source of major tourism flows, while in-strength measures its importance as a tourism attractor. Note that there are some countries that appear in all, or almost all, these centrality rankings. Thus, for the top 3 outbound GTN, the USA, Canada, France, Spain and Malaysia are among the highest ranked countries in all four categories, showing that a small group of countries enjoy a central position in global tourism flows. As captured in the outbound tourism network, USA had significantly in-degree centrality than the other countries, which indicates that it was the main tourist destination of a number of countries in 2013. Similarly, USA occupied a very advantageous position in the GTN for the other centrality indicators. Hong Kong, Mexico, Ireland, Indonesia, Uzbekistan, Andorra, Cambodia and Philippines were not the main destination for many tourist nationalities 
according their top 3 destinations in 2013, but in absolute terms (i.e. measured by in-strength) they received large tourist's inflows. This means that these countries have a high concentration in terms of their main source market being able to choose between focusing on them and implementing a diversification strategy.

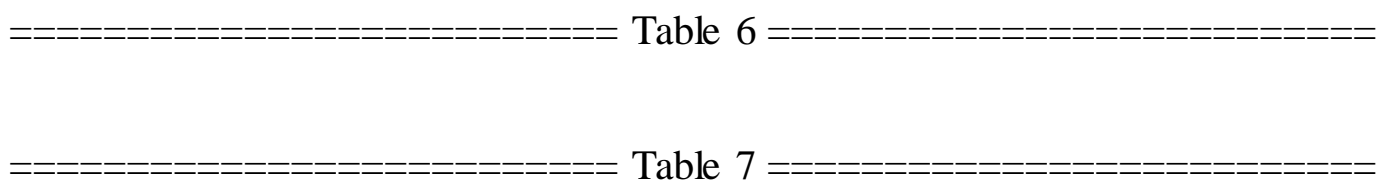

Apart from the USA, the central positions in the case of the top 3 inbound GTN, correspond to Canada, France, the UK, China, Russia and Malaysia. These countries have high centrality measures in the four categories. Other countries ranked highly are South Africa, Ukraine, Thailand, Brazil and Greece (in the top 3 outbound GTN) and Ukraine, Taiwan and Saudi Arabia (in the top 3 inbound GTN). Although Japan is a major tourist emitter to 11 different countries, however its corresponding out-strength is relatively small which indicates that the corresponding receptor countries are relatively small markets. The results also show that the global tourism market may be neglecting African destinations, probably due to the concerns about the geopolitical and economic instability, as well as about the Ebola outbreak in West Africa.

As regards Strongly Connected Components (SCC), Table 8 shows, in decreasing order of their size, the SCC present in the top 3 outbound and top 3 inbound GTN. As in the case of cliques, the main driver of SCC is geographical proximity. The larger SCC, though, contain more than one of those groups of close countries.

It is interesting also to analyse the results of a conventional Hierarchical Clustering Algorithm (with average linkage) applied to the top 3 outbound and inbound GTN. Table 9 shows the clusters that form if we consider a threshold of 7,732 and 45,722 in the respective dendrograms. These clusters compete across the economic, social, cultural, environmental and political dimensions in order to attract global tourism flows. Again, many of the clusters identified have a regional character. The distinct tourism spheres of influence of global and regional powers, such as the USA, China, Russia, South Africa, Brazil or Saudi Arabia, are also remarkable. It can be noted that no outbound/inbound clusters are formed grouping together European countries exclusively, reflecting the complex web of tourism relationships 
of those countries as well as the diverse travel motivations and preferences of their nationals. In other words, the closer integration of the European countries in the political and economic realms has not brought about a homogenization of their corresponding tourism relationships.

Table 9

Another way of studying the importance of geography in the GTN is measuring the degree of homophily between countries lying in the same continent. Table 10 shows the sum of links and tie strengths within and between each of six regions, namely North America, South America, Europe, Africa, Asia and Oceania. The resulting E-I indexes are -0.716 and 0.818 for the top 3 outbound and inbound GTN, respectively. Such large negative values clearly indicate that the tourism flows within these regions are much larger than between them. Intra-European travel is the largest worldwide outbound tourism market followed by Intra-Northamerican and Intra-Asian tourism. This means that the main destinations for most European countries are other European countries. This effect is less pronounced in the other two regions. For the inbound tourism, however, the rank is different, with intra-Asian flows totalling more than the sum of intra-European and intra-Northamerican flows. This means that, if we look from the perspective of source markets, it happens rather often that the main source markets of Asian destinations are other Asian countries. This effect is less pronounced in the cases of Europe or North America, whose tourism industry can thus be said to have a more global reach/attractiveness. Note that although the analysis carried out in this paper that considers two separate top inbound and top outbound networks is more complex that considering just a single weighted directed global tourism network, it leads to findings like the above that would remain hidden if the distinction between being a major source market or a major destination market is not emphasized.

Table 11 shows the triad census computed by UCINET 6.0. The rows corresponding to transitive triads are shown in bold. Note that there are two instances of triad 300 in the top 3 inbound GTN; that corresponds to the cliques of size three commented on above. No instances of that triad occur in the other networks. Triads 021U, 111D, 030T and 120D occur much more frequently in the top outbound GTN than in the top inbound GTN. Just the opposite occurs in the case of triads $021 \mathrm{D}, 111 \mathrm{U}$ and $120 \mathrm{U}$. Note that most of the triads are unconnected. This is a result of selecting only a few top tourism flows from/to each country, 
which filters out most of the possible links, leaving only the most relevant and thus facilitating the analysis.

Tables 12 and 13 show the significant (i.e. relatively frequent compared with a null model corresponding to a similar randomized networks) directed motifs found by the mfinder network motifs detection tool (Milo et al. 2002). Both three- and four-node motifs have been identified and some examples are shown. Note that three- and four-node motifs cannot form in the top 1 outbound or inbound networks. The analysis of three-node motifs reveals a common subgraph in the top 2-3 outbound and top 2-3 inbound GTN, the feedforward loop, with concentrations ranging from 10.6 to 20.7 (per thousand). The top 2 outbound example shown indicates that Colombia and USA are the top two tourist destinations of Venezuelan tourists and the same time that USA is the top two of tourist destinations of Colombian tourists. This is a typical transitive relationship. The top 3 outbound example is similar, with France being a top 3 tourism destination of both Canadian and Mexican tourists at the same time that Mexico is a top 3 destination for Canadians tourists. Different configurations of mutual dyads are relevant in top 2-3 outbound and inbound networks, such as the uplinked mutual dyad type. The example shown for the top 2 inbound network indicates that there exists a strong reciprocal relationship between USA and Canada and the same time that both countries are the main source markets for Bahamas. Another example is the reciprocal tourism links between Japan and Korea with both being major source markets of Guam. Also, feedback with two mutual dyads is much more frequent than in the random network. The example shown in Table 11 indicates the existence of a reciprocal major-destination market relationship between Indonesia and Malaysia together with Malaysia being a major destination of Thailand and Thailand a major destination of Indonesia. The other example involves the reciprocal relationship between Hong Kong and China with both being major source markets for Macao. Note that, although the commented examples are easy to justify, the main aim of the motifs detection analysis (more than finding specific examples) is identifying which local structures are present with a frequency that is significant compared with a similar randomized network. That indicates that they are significant and suggests that some underlying mechanisms must be in play to produce them.

The analysis of four-node directed motifs shows a scarce similarity between the networks, with the exception of motif 344 in the top 2-3 outbound GTN. Some specific four nodes connected subgraphs are, however, found to occur in a significant proportion, such as 
motif 94 in the top 3 inbound GTN, motif 2186 in the top 2 outbound GTN and motif 94 in the top 2 inbound GTN (concentrations of $31.8 \%, 21.8 \%$ and $15.3 \%$, respectively). In addition, some motifs with two mutual countries (motifs 5018, 350 and 414) are detected in the top 3 outbound and top 3 inbound GTN. The examples of motif 94 reflect, for instance, the intense reciprocal relation between USA and Canada, both of which are main source markets for Bermudas (and for Dominican Republic) while only one of them is a major source market for Bangladesh (or for American Samoa). Again, more important than the specific instance of the different motifs identified is the fact that these local structures are relatively more frequent than expected compared with in randomized version of the corresponding networks.

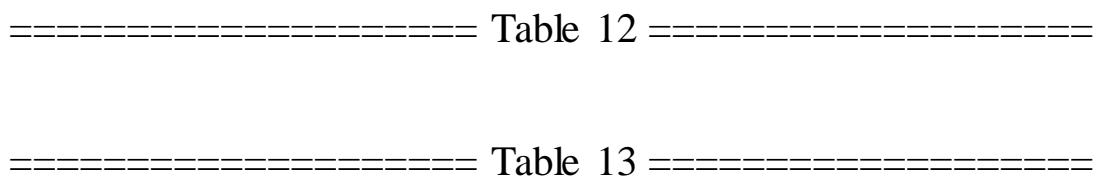

To further test the hypothesis that that the top $\mathrm{k}$ outbound and inbound GTN have developed their structure from local processes, we have applied an ERGM approach to identify the significant local substructures that are present or absent with more frequency than could be expected by simple randomness using ERGM estimation software (Handcock et al., 2017). Table 14 shows the Monte Carlo Maximum Likelihood (ML) estimates and standard deviation, and the significance tests performed on each parameter of the ERGM built, together with their Akaike information criterion (AIC) and Bayesian information criterion (BIC) goodness of fit measures. The results confirm that the global structure of the top GTN can be explained as emerging from the superposition of local effects. This is not surprising since, in the end, the major destinations from or to a country is defined at the local level. The inclusion of the so-called shared partner distribution terms, i.e. geometrically weighted indegree (Gwidegree) and geometrically weighted out-degree (Gwodegree), into the models accounted for the in-degree distribution and out-degree distribution for the top $\mathrm{k}$ outbound and inbound GTN. In particular, the Gwidegree (respectively, Gwodegree) is defined as the number of occurrences of a recipient country $\mathrm{i}$ (respectively, visitor country) that receive (respectively, emit) tourist flows from (respectively, to) other $\mathrm{m}$ countries, where $\mathrm{m}$ is the number of unlinked incoming (respectively, out-going) countries connected to country i. The order of $\mathrm{m}$ is indicated as Istar-2-3-4 (respectively, Ostar 2-3-4) configurations. The decay parameter represents the rate of declining marginal returns to link creation as $m$ increases. ML estimates for the coefficients for the edges terms are significant and negative for all models, 
indicating that the density of the top $\mathrm{k}$ outbound and inbound networks is below $50 \%$, a typical aspect of an observed network. With respect to top $\mathrm{k}$ outbound (respectively, top $\mathrm{k}$ inbound) GTN, the estimates (i.e. the log-odds) of the Istar-2-3-4 (respectively, Ostar 2-3-4) structures are significant, indicating a tendency for k-star configurations to form. In the case of the top 1 and top 2 outbound GTN, Istar-2 parameters are positive, indicating a propensity to form an Istar- 2 configuration. However, the positive sign of Istar-3 log-odds points to this configuration as being preferential in the top 3 outbound GTN. The same applies to the top $\mathrm{k}$ inbound GTN, as Ostar-2 and Ostar-3 configurations are prevalent in the top 1 and top 2 inbound GTN and in the top 3 inbound GTN, respectively. In general, lower-order stars are leading in the top $\mathrm{k}$ tourism GTN, as indicated by the significant and negative Gwidegree and Gwodegree parameters.

Table 14

\section{Conclusions, limitations and future research}

In this paper, the networks formed by the top $\mathrm{k}$ outbound and inbound global tourism flows have been studied. The main features of this GTN are scale-free degree and strength distributions, high degree centralization index, relatively high level of reciprocity, high level of transitivity, small world character and geographic homophily. A clustered structure has been detected and its origin traced to geographical, trade and cultural proximity. In particular, each main global and regional power seems to have its own tourism sphere of influence. Degree, in- and out-strength and betweenness centralities have been computed to identify the most central nodes. Among the players that occupy the most central positions in the top outbound GTN (mainly because they are top destinations for many countries) are USA, France, Spain, Canada and Malaysia. On the other hand, in the top inbound GTN, and mainly because they are top source markets for many countries, we find USA, Canada, France, the UK, China, Russia and Malaysia. The PageRank index, which corresponds to the frequency with which a country would be visited by a tourist travelling around the world randomly following the directed links of the GTN (with a probability proportional to their respective weights), provide a different centrality measure which, for the top outbound GTN, identify as central countries such as USA, Malaysia, France and Spain but also Mexico, South Africa, Thailand, Israel, Mauritius, Hong Kong and Greece. For the inbound tourism network the high PageRank countries are again USA, France, South Africa and Hong Kong, but also Canada, China, Germany, Argentina and Russia. 
For all regions, intra-regional travel is the main source of outbound and inbound tourism due to geographical, cultural and economic reasons. In particular, it has been found that while the main destinations for most European countries are other European countries, a similar effect is less pronounced in Asia or North America. For the inbound tourism, on the contrary, it is in Asia where the main source markets are other Asian countries, with a similar effect less pronounced in the cases of Europe or North America, whose main source markets are more geographically diversified. The minor role played by the African continent, plagued by social and political instabilities, in the GTN is also detected by the NA carried out.

A number of network motifs have been identified that occur with a significantly high frequency. Those motifs include transitive feedforward loops and different one and two mutual-dyads subgraphs. An ERGM analysis confirms that some specific local substructures can explain the observed topology of these networks. The insight provided by the results is that the observed global tourism patterns emerge from bottom-up processes that work at the local level and that, in the end, involve multiple individuals making independent, personal decisions.

Finally, mention should be made of the limitations of the study related to static dimension of the GTN. The next step would be to analyse the GTN using a longitudinal approach. Investigating the relationships between the worldwide air transportation network and tourism flows on a global scale is also another interesting research endeavour. Building and analysing global tourism flow networks for different market segments (e.g. institutionalized versus non-institutionalized) can provide a disaggregated picture of the tourism phenomenon. This will require using big data techniques to obtain data indirectly from on-line and social media sources as conventional statistical databases have obvious limitations about the granularity, the lag and the type of data that are available. Finally, the NA methodology can also be deployed at the regional level and include the interactions between the different agents involved in the tourism industry (e.g. lodgings, air carriers, local suppliers, services in destination, etc.) thus reflecting the strong interdependence among them.

\section{References}

Asero, V., Gozzo, S. and Tomaselli, V., "Building Tourism Networks through Tourist Mobility", Journal of Travel Research, 55, 6 (2016) 751-763

Baggio, R., "The web graph of a tourism system", Physica A, 379 (2007) 727-734

Baggio, R., "Collaboration and cooperation in a tourism destination: a network science approach", Current Issues in Tourism, 14, 2 (2011) 183-189 
Baggio, R., "Complex tourism systems: a visibility graph approach", Kybernetes, 43 (2014a) $445-461$

Baggio, R., "Creativity and the Structure of Tourism Destination Networks", International Journal of Tourism Sciences, 14, 1 (2014b) 137-154

Baggio, R. and Cooper, C., "Knowledge transfer in a tourism destination: the effects of a network structure", The Service Industries Journal, 30, 10 (2010) 1757-1771

Baggio, R., Scott, N. and Cooper, C., "Network Science: A Review Focused on Tourism", Annals of Tourism Research, 37, 3 (2010) 802-827

Baggio, R. and Del Chiappa, G., "Real and virtual relationships in tourism digital ecosystems", Information Technology \& Tourism, 14, 1 (2014) 3-19

Baggio, R. and Sainaghi, R., "Mapping time series into networks as a tool to assess the complex dynamics of tourism systems", Tourism Management, 54 (2016) 23-33

Baggio, R., "Network science and tourism - the state of the art", Tourism Review, 72, 1 (2017) 120-131

Belyi, A., Bojic, I., Sobolevsky, S., Sitko, I., Hawelka, I., Rudikova, L., Kurbatski, A. and Ratti, C., "Global multi-layer network of human mobility", International Journal of Geographical Information Science, 31, 7 (2017) 1381-1402

Bendle, L.J., "The structures and flows of a large tourist itinerancy network", Current Issues in Tourism, 21, 1 (2018) 103-122

Bertelli, P., Buffa, F. and Martini, U., "The coordinating DMO or coordinators in the DMO? - an alternative perspective with the help of network analysis", Tourism Review, 70, 1 (2015) $24-42$

Borgatti, S.P., Everett, M.G. and Freeman, L.C., Ucinet for Windows: Software for Social Network Analysis, Harvard, MA: Analytic Technologies, 2002

Brin, S. and Page, L., "The Anatomy of a Large-Scale Hypertextual Web Search Engine", Computer Networks and ISDN Systems, 30 (1998) 107-117

Casanueva, C., Gallego, A. and García-Sánchez, M.R., "Social network analysis in tourism", Current Issues in Tourism, 19, 12 (2016) 1190-1209

Chung, H.C., Chung, N. and Nam, Y., "A Social Network Analysis of Tourist Movement Patterns in Blogs: Korean Backpackers in Europe", Sustainability, 9 (2017) 2251

Clauset, A., Shalizi, C.R. and Newman, M.E.J., "Power-law distributions in empirical data", SIAM Review, 51, 4 (2009) 661-703

da Fontoura Costa, L. and Baggio, R., "The web of connections between tourism companies: Structure and dynamics", Physica A, 388 (2009) 4286-4296

da Fontoura Costa, L., Oliveira Jr, O.N., Travieso, G., Rodrigues, F.A., Ribeiro Villas Boas, P., Antiqueira, L., Palhares Viana, M. and Correa Rocha, L.E., "Analyzing and modeling realworld phenomena with complex networks: a survey of applications", Advances in Physics, 60, (2011) 329-412

D’Agata, R., Gozzo, S. and Tomaselli, V., 'Network analysis approach to map tourism mobility", Quality \& Quantity, 47 (2013) 3167-3184

Del Chiappa, G. and Presenza, A., "The use of network analysis to assess relationships among stakeholders within a tourism destination: An Empirical Investigation on Costa SmeraldaGallura, Italy", Tourism Analysis, 18 (2013) 1-13 
González-Díaz, B., Gómez, M. and Molina, A., "Configuration of the hotel and non-hotel accommodations: An empirical approach using network analysis", International Journal of Hospitality Management, 48 (2015) 39-51

Grama, C.N. and Baggio, R., "A network analysis of Sibiu County, Romania", Annals of Tourism Research, 47 (2014) 77-95

Gretzel, U., Sigala, M, Xiang, Z. and Koo, C., "Smart tourism: foundations and developments", Electronics Markets, 25 (2015) 179-188

Guimerà, R., Mossa, S. Turtschi, A. and Amaral, L.A.N., "The worldwide air transportation network: Anomalous centrality, community structure, and cities' global roles", PNAS, 102, 22 (2005) 7794-7799

Guo, Y., Zhang, J., Yang, Y. and Zhang, H., "Modeling the Fluctuation Patterns of Monthly Inbound Tourist Flows to China: A Complex Network Approach", Asia Pacific Journal of Tourism Research, 20, 8 (2015) 942-953

Handcock, M., Hunter, D., Butts, C., Goodreau, S., Krivitsky, P. and Morris, M., ergm: Fit, Simulate and Diagnose Exponential-Family Models for Networks (2017) The Statnet Project (<URL: http//www.statnet.org>). Rpackage version 3.8.0, <URL: https:/CRAN.Rproject.org/package=ergm $>$.

Hawelka, B., Sitko, I., Beinat, E., Sobolevsky, S., Kazakopoulos, P. and Ratti, C., "Geolocated Twitter as proxy for global mobility patterns", Cartography and Geographic Information Science, 41, 3 (2014) 260-271

Hernández, J.M. and González-Martel, C., "An evolving model for the lodging-service network in a tourism destination", Physica A, 482 (2017) 296-307

Hwang, Y.H., Gretzel, U. and Fesenmeier, D.R., "Multicity Trip Patterns. Tourists to the United States", Annals of Tourism Research, 33, 4 (2006) 1057-1078

Jørgensen, M.T., "Synergistic Social Network Analysis: A Synergistic Approach to Qualitative and Quantitative Network Analysis", Tourism Analysis, 21 (2016) 559-576

Junker, C., Akbar, Z. and Cuquet, M., "The Network Structure of Visited Locations According to Geotagged Social Media Photos", in: Camarinha-Matos, L., Afsarmanesh, H. and Fornasiero, R. (eds), Collaboration in a Data-Rich World. PRO-VE 2017. IFIP Advances in Information and Communication Technology, vol. 506, Springer (2017) 276-283

Karl, M. and Reintinger, C., 'Investigating Tourists' Destination Choices - An Application of Network Analysis", European Journal of Tourism Research, 15 (2017) 112-130

Khalilzadeh, J., "Demonstration of exponential random graph models in tourism studies: Is tourism a means of global peace or the bottom line?", Annals of Tourism Research, 69 (2018) $31-41$

Lee, S.H., Choi, J.Y., Yoo, S.H. and Oh, Y.G., "Evaluating spatial centrality for integrated tourism management in rural areas using GIS and network analysis", Tourism Management, 34 (2013) 14-24

Leung, X.Y., Wang, F., Wu, B., Bai, B., Stahura, K.A. and Xie, Z., "A Social Network Analysis of Overseas Tourist Movement Patterns in Beijing: the Impact of the Olympic Games", International Journal of Tourism Research, 14 (2012) 469-484

Li, J., Yang, M. and Pan, B., 'Network Analysis of Navigation Paths of Tourists' Trip Planning and Power Structure of the Online Tourism in China", Asia Pacific Journal of Tourism Research, 20, 1 (2015) 1451-1465 
Liu, F., Zhang, J., Zhang, J., Chen, D., Liu, Z. and Lu, S., "Roles and Functions of Tourism Destinations in Tourism Region of South Anhui: A Tourist Flow Network Perspective", Chinese Geographical Science, 22, 6 (2012) 755-764

Liu, B., Huang, S. and Fu, H., "An application of network analysis on tourist attractions: The case of Xinjiang, China", Tourism Management, 58 (2017) 132-141

Lordan, O., Sallan, J.M., Simo, P. and González-Prieto, D., "Robustness of airline alliance route networks", Communications in Nonlinear Science and Numerical Simulation, 22 (2015) $587-595$

Luo, Q. and Zhong, D., "Using social network analysis to explain communication characteristics of travel-related electronic word-of-mouth on social networking sites", Tourism Management, 46 (2015) 274-282

Luthe, T., Wyss, R. and Schuckert, M., "Network governance and regional resilience to climate change: empirical evidence from mountain tourism communities in the Swiss Gotthard region”, Regional Environmental Change, 12, 4 (2012) 839-854

Luthe, T. and Wyss, R., "Resilience to climate change in a cross-scale tourism governance context: a combined quantitative-qualitative network analysis", Ecology and Society, 21, 1 (2016) 27

Miguéns, J.I.L. and Mendes, J.F.F., "Travel and tourism: Into a complex network", Physica A, 387 (2008) 2963-2971

Milo, R., Shen-Orr, S., Itzkovitz, S., Kashtan, N., Chklovskii, D. and Alon, U., "Network Motifs: Simple Building Blocks of Complex Networks", Science, 298, 5594 (2002) 824-827

Newman, M.E.J., "The Structure and Function of Complex Networks", SIAM Review, 45, 2 (2003) 167-256

Park, S., Tussyadiah, I.P, Mazanec, J.A. and Fesenmeier, D.R., "Travel Personae of American Pleasure Travelers: A Network Analysis", Journal of Travel \& Tourism Marketing, 27, 8 (2010) 797-811

Peng, H., Zhang, J., Liu, Z., Lu, L. and Yang, L., "Network analysis of tourist flows: a crossprovincial boundary perspective", Tourism Geographies, 18, 5 (2016) 561-586

Piazzi, R., Baggio, R., Neidhardt, J., Werthner, H., "Destinations and the Web: A Network Analysis View", Information Technology \& Tourism, 13, 3 (2012) 215-228

Presenza, A. and Cipollina, M., "Analysing tourism stakeholders networks", Tourism Review, 65, 4 (2010) 17-30

Provenzano, D. and Baggio, R., " The contribution of human migration to tourism: The VFR travel between the EU28 member states", International Journal of Tourism Research, 19 (2017) 412-420

Provenzano, D., Hawelka, B. and Baggio, R., "The mobility network of European tourists: a longitudinal study and a comparison with geo-located Twitter data", Tourism Review, 73, 1 (2018) 28-43

Sainaghi, R. and Baggio, R., "Complexity traits and dynamics of tourism destinations", Tourism Management, 63 (2017) 368-382

Scott, N., Cooper, C. and Baggio, R, "DESTINATION NETWORKS. Four Australian Cases", Annals of Tourism Research, 35, 1 (2008) 169-188

Scott, N., Baggio, R. and Cooper, C., "Network Analysis Methods for Modeling Tourism Inter-Organizational Systems", in Tourism Sensemaking: Strategies to Give Meaning to Experience, Advances in Culture, Tourism and Hospitality Research vol. 5 (2011) 177-221 
Serrano, M.A. and Boguná, M., "Topology of the world trade web", Physical Review E, 68, (2003) 015101(R)

Shih, H.Y., "Network characteristics of drive tourism destinations: An application of network analysis in tourism", Tourism Management, 27 (2006) 1029-1039

Taczanowska, K., Bielanski, M., González, L.M., Garcia-Massó, X. and Toca-Herrera, J.L., "Analyzing Spatial Behavior of Backcountry Skiers in Mountain Protected Areas Combining GPS Tracking and Graph Theory", Symmetry, 9, (2017) 317

Tran, M.T.T., Jeeva, A.S. and Pourabedin, Z., "Social network analysis in tourism services distribution channels", Tourism Management Perspectives, 18 (2016) 59-67

Tsiotas, D., "The imprint of tourism on the topology of maritime networks: evidence from Greece", Anatolia, 28, 1 (2017) 52-68

Ulubasoglu, MA, and BR Hazari. "Zipf's law strikes again: the case of tourism”. Journal of Economic Geography 4, 4, (2004) 459

UNWTO, Tourism statistics-Outbound tourism- rips abroad by resident visitors to countries of destination (basis: arrivals in destination countries), World Tourism Organization (2016a). Retrieved May 2017, http://statistics.unwto.org/content/yearbook-tourism-statistics

UNWTO, Tourism statistics- Arrivals of non-resident visitors at national borders, by nationality, World Tourism Organization (2016b) Retrieved May 2017, http:/statistics. unwto.org/content/yearbook-tourism-statistics

UNWTO (2011). Tourism Towards 2030, World Tourism Organization

UNWTO (2017). Tourism Highlights, 2017 Edition, World Tourism Organization

Wäsche, H., "Interorganizational cooperation in sport tourism: A social network analysis", Sport Management Review, 18 (2015) 542-554

Williams, N.L., Inversini, A., Ferdinand, N. and Buhalis, D., "Destination eWOM: A macro and meso network approach?”, Annals of Tourism Research, 64 (2017) 87-101

WTTC (2017). Travel \& Tourism: Global Economic Impact \& Issues 2017. London: World Travel \& Tourism Council

Wyss, R., Luthe, T. and Abegg, B., "Building resilience to climate change - the role of cooperation in alpine tourism networks", Local Environment, 20, 8 (2015) 908-922

Ying, T., Norman, W.C. and Zhou, Y., "Online Networking in the Tourism Industry: A Webometrics and Hyperlink Network Analysis", Journal of Travel Research, 55, 1 (2016) 1633

Zhou, M., Wu, G., Xu, H., "Structure and formation of top networks in international trade, 2001-2010", Social Networks, 44 (2016), 9-21 


\section{List of figures and table captions}

Table 1. Ranking of top 10 countries with the greatest contribution (in absolute and relative terms) of tourism to GDP in the year 2016

Table 2. Summary of Tourism NA studies

Table 3. Some characterization measures of top $\mathrm{k}$ outbound and inbound GTN

Table 4. Estimates of the Power Law exponents, cut-off values and KS test p-values

Table 5. Countries with highest PageRank centralities (commonalities are indicated in bold)

Table 6. Countries with highest in-degree, in- and out-strength and betweenness centrality for top 3 outbound GTN (countries in all four rankings shown in bold, countries in three of the four rankings shown in italics)

Table 7. Countries with highest out-degree, in- and out-strength and betweenness centrality for top 3 inbound GTN (countries in all four rankings shown in bold, countries in three of the four rankings shown in italics)

Table 8. Strongly Connected Components

Table 9. Clusters identified by Hierarchical Clustering Algorithm

Table 10. Cross-regional distribution of tourism flows

Table 11. GTN triad census (transitive triads in bold)

Table 12. Three-node motifs in the top k outbound and inbound GTN

Table 13. Four-node motifs in the top k outbound and inbound GTN

Table 14. ERGM fit for the top k outbound and inbound GTM (Monte Carlo ML method)

Figure 1. International tourist arrivals by destination region (past data and projections)

Figure 2. Top 1, 2 and 3 outbound GTN

Figure 3. Top 1, 2 and 3 inbound GTN 


\begin{tabular}{|l|c|l|c|}
\hline \multicolumn{1}{|c|}{ Country } & GDP share (US\$bn) & \multicolumn{1}{|c|}{ Country } & GDP share (\%) \\
\hline USA & 1509.2 & British Virgin Islands & $95.9 \%$ \\
\hline China & 1000.7 & Aruba & $88.1 \%$ \\
\hline Germany & 376.7 & Maldives & $79.4 \%$ \\
\hline Japan & 343.2 & Former Netherlands Antilles & $63.6 \%$ \\
\hline United Kingdom & 283.2 & Antigua and Barbuda & $60.4 \%$ \\
\hline France & 221.3 & Seychelles & $58.1 \%$ \\
\hline India & 208.9 & Macau & $57.2 \%$ \\
\hline Italy & 207.6 & Anguilla & $56.6 \%$ \\
\hline Spain & 177.2 & Bahamas & $44.8 \%$ \\
\hline Mexico & 165.9 & Cape Verde & $44.5 \%$ \\
\hline
\end{tabular}

Table 1. Ranking of top 10 countries with the greatest contribution (in absolute and relative terms) of tourism to GDP in the year 2016 


\begin{tabular}{|c|c|}
\hline Research topic & Papers \\
\hline $\begin{array}{l}\text { Tourism destination networks } \\
\text { (real-world relationships) }\end{array}$ & $\begin{array}{l}\text { Scott et al. (2008), da Fontoura Costa and Baggio (2009), } \\
\text { Baggio and Cooper (2010), Presenza and Cipollina (2010), } \\
\text { Baggio (2011), Scott et al. (2011), Luthe et al. (2012), Del } \\
\text { Chiappa and Presenza (2013), Baggio (2014b), Baggio and Del } \\
\text { Chiappa (2014), Bertelli et al. (2015), Grama and Baggio } \\
\text { (2014), Wäsche (2015), Wyss et al. (2015), Jørgensen (2016), } \\
\text { Luthe and Wyss (2016), Tran et al. (2016) }\end{array}$ \\
\hline $\begin{array}{l}\text { Tourism destination networks } \\
\text { (web links) }\end{array}$ & $\begin{array}{l}\text { Baggio (2007), Piazzi et al. (2012), Baggio and Del Chiappa } \\
\text { (2014), Ying et al. (2016) }\end{array}$ \\
\hline $\begin{array}{l}\text { Tourist itinerancy networks } \\
\text { (mobility/travelling patterns) }\end{array}$ & $\begin{array}{l}\text { Shih (2006), Hwang et al. (2016), Leung et al. (2012), Liu et } \\
\text { al. (2012), Bendle (2018), D'Agata et al. (2013), Asero et al. } \\
\text { (2016) }\end{array}$ \\
\hline $\begin{array}{l}\text { Attractions/villages spatial } \\
\text { networks }\end{array}$ & Lee et al. (2013), Peng et al. (2016), Liu et al. (2017) \\
\hline $\begin{array}{l}\text { Tourism dynamics (time } \\
\text { series) }\end{array}$ & $\begin{array}{l}\text { Baggio (2014a), Guo et al. (2015), Baggio and Sainaghi (2016), } \\
\text { Sainaghi and Baggio (2017) }\end{array}$ \\
\hline $\begin{array}{l}\text { Social media/Web } \\
\text { Navigation patterns }\end{array}$ & $\begin{array}{l}\text { Hawelka et al. (2014), Li et al. (2015), Luo and Zhong (2015), } \\
\text { Williams et al. (2017), Junker et al. (2017), Chung et al. (2017), } \\
\text { Provenzano et al. (2018) }\end{array}$ \\
\hline Tourism flows & Miguéns and Mendes (2008), González-Díaz et al. (2015) \\
\hline $\begin{array}{l}\text { Tourism and } \\
\text { migration/human mobility }\end{array}$ & Belyl et al. (2017), Provenzano and Baggio (2017) \\
\hline Surveys & Baggio et al. (2010), Casanueva et al. (2016), Baggio (2017) \\
\hline Other & $\begin{array}{l}\text { Park et al. (2010), Karl and Reintinger (2017), Tsiotas (2017), } \\
\text { Hernández and González-Martel (2017), Taczanowska et al. } \\
\text { (2017), Khalilzadeh (2018) }\end{array}$ \\
\hline
\end{tabular}

Table 2. Summary of Tourism NA studies 


\begin{tabular}{|c|c|c|c|}
\hline & Top 1 outbound & Top 2 outbound & Top 3 outbound \\
\hline \# ties & 214 & 428 & 642 \\
\hline Density & 0.005 & 0.009 & 0.014 \\
\hline Average geodesic distance & 2.134 & 3.799 & 3.439 \\
\hline Diameter & 7 & 10 & 10 \\
\hline Average degree & 1.00 & 1.99 & 2.99 \\
\hline In-degree centralization & 0.291 & 0.479 & 0.704 \\
\hline Average strength & $1,068,014$ & $1,376,952$ & $1,515,535$ \\
\hline \#mutual/\#asymm/\#null dyads & $5 / 205 / 22,795$ & $10 / 409 / 22,586$ & $22 / 598 / 22,385$ \\
\hline Arc/Dyad reciprocity & $0.047 / 0.024$ & $0.047 / 0.024$ & $0.069 / 0.035$ \\
\hline Transitivity & 0.000 & 0.159 & 0.219 \\
\hline & Top 1 inbound & Top 2 inbound & Top 3 inbound \\
\hline \# ties & 148 & 296 & 444 \\
\hline Density & 0.003 & 0.006 & 0.010 \\
\hline Average geodesic distance & 1.669 & 2.976 & 3.544 \\
\hline Diameter & 6 & 9 & 14 \\
\hline Average degree & 0.69 & 1.37 & 2.03 \\
\hline Out-degree centralization & 0.129 & 0,201 & 0.273 \\
\hline Average strength & $2,511,134$ & $3,291,240$ & $3,567,227$ \\
\hline \#mutual/\#asymm/\#null dyads & $10 / 128 / 22,653$ & $24 / 245 / 22,522$ & $44 / 347 / 22,400$ \\
\hline Arc/Dyad reciprocity & $0.135 / 0.072$ & $0.164 / 0.089$ & $0.202 / 0.113$ \\
\hline Transitivity & 0.000 & 0.099 & 0.182 \\
\hline
\end{tabular}

Table 3. Some characterization measures of top k outbound and inbound GTN 


\begin{tabular}{|c|c|c|c|c|c|c|}
\cline { 2 - 7 } \multicolumn{1}{c|}{} & \multicolumn{3}{c|}{ In-degree } & \multicolumn{3}{c|}{ In-strength } \\
\cline { 2 - 7 } \multicolumn{1}{c|}{} & $\alpha$ & $\mathrm{x}_{\text {min }}$ & KS p-value & $\alpha$ & Xmin $_{1}$ & KS p-value \\
\hline Top 1 outbound & 2.10 & 3 & 0.980 & 1.30 & 39,386 & 0.388 \\
\hline Top 2 outbound & 2.13 & 4 & 0.965 & 1.30 & 35,980 & 0.208 \\
\hline Top 3 outbound & 2.22 & 7 & 0.997 & 1.35 & 89,074 & 0.302 \\
\hline
\end{tabular}

\begin{tabular}{|l|c|c|c|c|c|c|}
\cline { 2 - 7 } \multicolumn{1}{c|}{} & \multicolumn{3}{c|}{ Out-degree } & \multicolumn{3}{c|}{ Out-strength } \\
\cline { 2 - 7 } \multicolumn{1}{c|}{} & $\alpha$ & $\mathrm{x}_{\min }$ & KS p-value & $\alpha$ & $\mathrm{x}_{\text {min }}$ & KS p-value \\
\hline Top 1 inbound & 2.45 & 2 & 0.997 & 1.70 & $1,442,567$ & 0.809 \\
\hline Top 2 inbound & 2.23 & 2 & 0.980 & 1.71 & $1,442,567$ & 0.755 \\
\hline Top 3 inbound & 2.19 & 2 & 0.999 & 1.78 & $1,967,830$ & 0.924 \\
\hline
\end{tabular}

Table 4. Estimates of the Power Law exponents, cut-off values and KS test p-values 


\begin{tabular}{|c|c|c|}
\hline Top 1 outbound & Top 2 outbound & Top 3 outbound \\
\hline $\begin{array}{l}\text { USA }(\mathbf{4 8 . 2 7}) \\
\text { Mexico (41.18) } \\
\text { South Africa (14.17) } \\
\text { Thailand (12.59) } \\
\text { Bots wana (12.48) } \\
\text { Malaysia (12.13) } \\
\text { France (10.05) } \\
\text { Spain (9.80) } \\
\text { Ukraine (3.07) } \\
\text { Israel (2.74) } \\
\text { New Caledonia (1.85) } \\
\text { Vanuatu (1.72) } \\
\text { Mauritius (1.60) } \\
\text { Hong Kong (1.35) } \\
\text { Benin (1.15) } \\
\text { South Sudan (1.13) } \\
\text { Seychelles (1.11) } \\
\text { Greece (1.04) } \\
\text { Ethiopia (0.98) } \\
\text { Philippines (0.97) }\end{array}$ & $\begin{array}{l}\text { USA (55.75) } \\
\text { Mexico (29.68) } \\
\text { Canada }(19.01) \\
\text { Malaysia (13.00) } \\
\text { Thailand (12.29) } \\
\text { South Africa (8.10) } \\
\text { France (6.56) } \\
\text { Spain (6.16) } \\
\text { Botswana (5.82) } \\
\text { Hong Kong (4.03) } \\
\text { Indonesia (3.77) } \\
\text { Ukraine (2.63) } \\
\text { Israel (1.90) } \\
\text { Philippines (1.75) } \\
\text { Andorra (1.39) } \\
\text { Greece (1.03) } \\
\text { Benin (1.02) } \\
\text { Ethiopia (1.01) } \\
\text { Mauritius (0.85) } \\
\text { New Caledonia }(0.85)\end{array}$ & $\begin{array}{l}\text { USA (46.72) } \\
\text { Mexico }(\mathbf{2 3 . 1 1}) \\
\text { Canada }(\mathbf{1 5 . 2 5}) \\
\text { Thailand (15.21) } \\
\text { Malaysia (14.26) } \\
\text { France (12.13) } \\
\text { Spain (10.08) } \\
\text { South Africa (7.12) } \\
\text { Hong Kong (5.95) } \\
\text { Bots wana (4.40) } \\
\text { Indonesia (3.74) } \\
\text { Philippines (2.85) } \\
\text { Ukraine (2.63) } \\
\text { Greece (2.09) } \\
\text { Andorra (1.97) } \\
\text { Cambodia (1.83) } \\
\text { Israel (1.75) } \\
\text { Mauritius (1.68) } \\
\text { Benin (1.12) } \\
\text { Ethiopia (1.02) }\end{array}$ \\
\hline Top 1 inbound & Top 2 inbound & Top 3 inbound \\
\hline $\begin{array}{l}\text { USA (28.62) } \\
\text { Canada (24.82) } \\
\text { China (10.49) } \\
\text { Hong Kong (9.18) } \\
\text { Germany (6.15) } \\
\text { Argentina (5.75) } \\
\text { Chile (5.35) } \\
\text { France (5.29) } \\
\text { Saudi Arabia (5.03) } \\
\text { South Africa (4.91) } \\
\text { Zimbabwe (4.66) } \\
\text { Kuwait (4.54) } \\
\text { Russian Federation }(\mathbf{4 . 2 1}) \\
\text { Ukraine (3.85) } \\
\text { Kazakhstan (3.28) } \\
\text { Iran (3.28) } \\
\text { Singapore (3.28) } \\
\text { Uzbekistan (3.28) } \\
\text { Iraq (3.28) } \\
\text { Indonesia (3.05) }\end{array}$ & $\begin{array}{l}\text { USA }(\mathbf{2 8 . 6 6 )} \\
\text { Canada (16.14) } \\
\text { China (12.42) } \\
\text { Mexico (9.61) } \\
\text { Hong Kong (9.15) } \\
\text { Germany (7.28) } \\
\text { U.K. (6.66) } \\
\text { France (6.27) } \\
\text { Russian Federation (5.95) } \\
\text { Kazakhstan (4.30) } \\
\text { Ukraine (3.63) } \\
\text { Argentina (3.55) } \\
\text { South Africa (3.48) } \\
\text { Uzbekistan (2.83) } \\
\text { Macao (2.51) } \\
\text { Chile (2.10) } \\
\text { Brazil (2.01) } \\
\text { New Zealand (1.93) } \\
\text { Zimbabwe (1.94) } \\
\text { Lesotho (1.71) }\end{array}$ & $\begin{array}{l}\text { USA (28.53) } \\
\text { Canada (14.97) } \\
\text { China (12.27) } \\
\text { Hong Kong (8.92) } \\
\text { UK (8.90) } \\
\text { Mexico (8.71) } \\
\text { Germany (6.87) } \\
\text { France (6.44) } \\
\text { Russian Federation (5.82) } \\
\text { Kazakhstan (5.15) } \\
\text { Uzbekistan (3.70) } \\
\text { Argentina (3.62) } \\
\text { Ukraine (3.07) } \\
\text { South Africa (3.04) } \\
\text { Macao (3.73) } \\
\text { Brazil (2.05) } \\
\text { Kyrgyzstan (1.97) } \\
\text { Taiwan (1.82) } \\
\text { Chile (1.76) } \\
\text { New Zealand (1.75) }\end{array}$ \\
\hline
\end{tabular}

Table 5. Countries with highest PageRank centralities (commonalities are indicated in bold) 


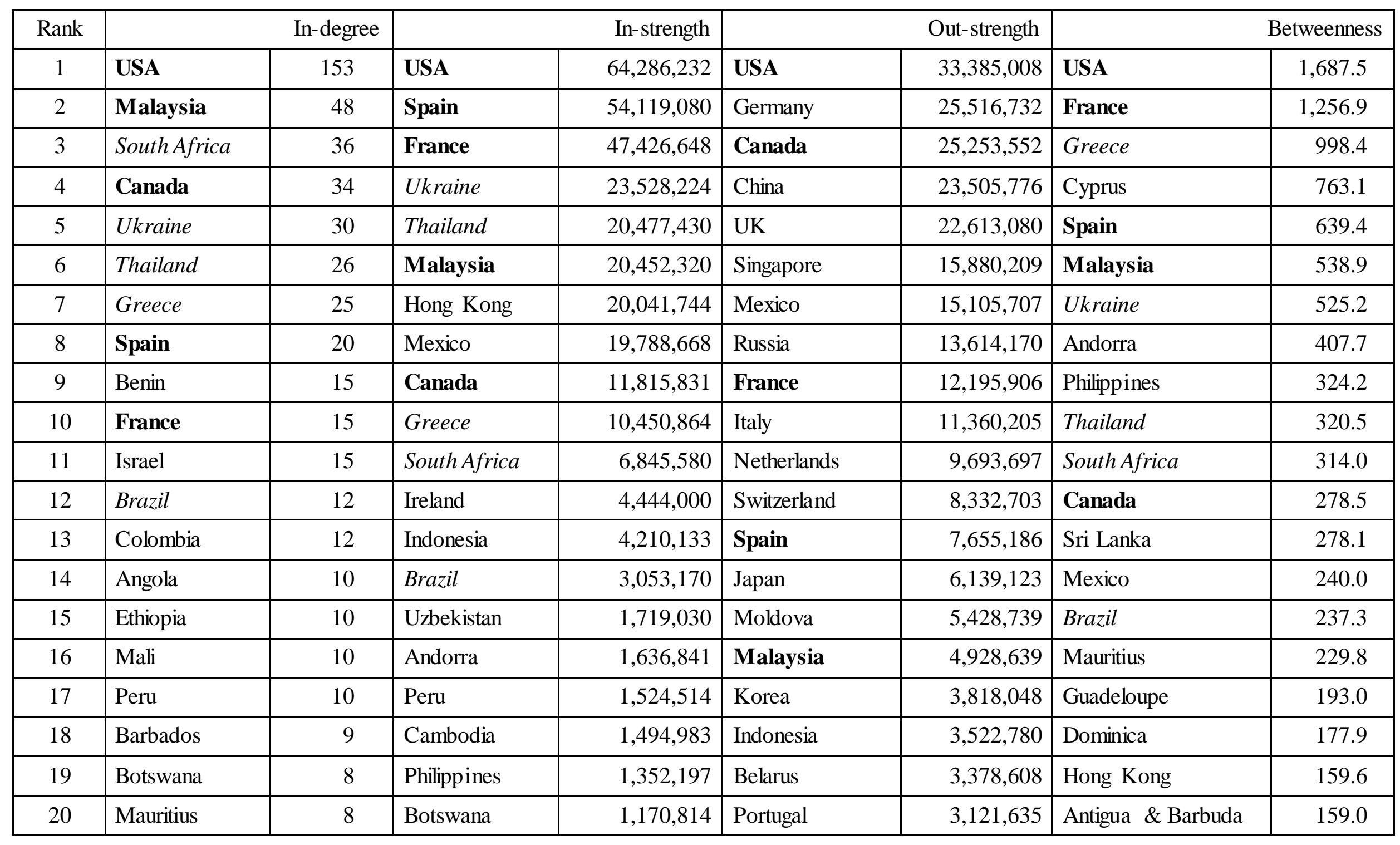

Table 6. Countries with highest in-degree, in- and out-strength and betweenness centrality for top 3 outbound GTN (countries in all four rankings shown in bold, countries in three of the four rankings shown in italics) 


\begin{tabular}{|c|c|c|c|c|c|c|c|c|}
\hline \multirow{2}{*}{$\begin{array}{c}\text { Rank } \\
1\end{array}$} & \multicolumn{2}{|c|}{ Out-degree } & \multicolumn{2}{|r|}{ Out-strength } & \multicolumn{2}{|r|}{ In-strength } & \multicolumn{2}{|c|}{ Betweenness } \\
\hline & USA & 60 & Hong Kong & $84,832,176$ & China & $102,787,472$ & USA & 881.1 \\
\hline 2 & UK & 33 & China & $80,393,624$ & Hong Kong & $43,955,216$ & China & 682.5 \\
\hline 4 & Canada & 23 & Germany & $47,712,272$ & Italy & $34,317,984$ & Russia & 544.2 \\
\hline 5 & China & 18 & UK & $46,682,896$ & Spain & $33,729,496$ & UK & 531.4 \\
\hline 7 & Russia & 16 & Canada & $27,106,348$ & France & $26,525,662$ & Moldova & 337.5 \\
\hline 8 & Japan & 11 & Russia & $25,119,952$ & Macao & $26,396,392$ & Romania & 325.0 \\
\hline 9 & Australia & 10 & Macao & $20,740,332$ & Mexico & $19,788,668$ & Taiwan & 263.5 \\
\hline 10 & New Zealand & 10 & Singapore & $15,567,116$ & Ukraine & $19,056,400$ & India & 261.3 \\
\hline 14 & Brazil & 5 & Switzerland & $12,985,489$ & Sweden & $11,726,955$ & Egypt & 98.2 \\
\hline 15 & Italy & 5 & Taiwan & $10,499,512$ & Turkey & $11,304,056$ & Greece & 96.0 \\
\hline 16 & Korea & 5 & Saudi Arabia & $9,417,797$ & UK & $9,883,000$ & Tanzania & 94.0 \\
\hline 17 & Netherlands & 5 & Malaysia & $8,376,649$ & Thailand & $9,424,997$ & Saudi Arabia & 90.3 \\
\hline 18 & Saudi Arabia & 5 & Slovakia & $7,667,000$ & South Africa & $8,022,524$ & Turkey & 86.0 \\
\hline 19 & Taiwan & 5 & Kazakhstan & $7,095,667$ & Korea & $7,796,934$ & Australia & 82.8 \\
\hline 20 & Malaysia & 4 & Moldova & $6,416,210$ & Singapore & $6,639,671$ & Malaysia & 81.0 \\
\hline
\end{tabular}

Table 7. Countries with highest out-degree, in- and out-strength and betweenness centrality for top 3 inbound GTN (countries in all four rankings shown in bold, countries in three of the four rankings shown in italics) 
Top 3 outbound GTN

\{Andorra, Cambodia, Canada, Cyprus, France, Greece, Hong Kong, Indonesia, Italy, Malaysia, Mexico, Nepal, Philippines, Spain, Sri Lanka, Thailand, Ukraine, USA\} \{Antigua and Barbuda, Barbados, Dominica, French Guiana, Guadeloupe, Martinique, Santa Lucia, Suriname, Trinidad and Tobago\}, \{Botswana, Mauritius, South Africa\}, \{Brazil, Colombia, Peru\}, \{French Polynesia, New Caledonia, Vanuatu\}, \{Benin, Mali\}, \{Dominican Republic, Haiti\}, \{Ethiopia, Uganda

\section{Top 3 inbound GTN}

\{Belarus, Bulgaria, Greece, Hungary, Kazakhstan, Kyrgyzstan, Moldova, Romania, Russia, Turkey, Ukraine, Uzbekistan\}, \{Canada, China, France, Hong Kong, Japan, Korea, Macao, Mexico, Taiwan, UK, USA\}, \{Argentina, Brazil, Bolivia, Chile, Paraguay, Peru, Uruguay\}, \{Azerbaijan, Armenia, Georgia, Iraq, Iran), \{Lesotho, Mozambique, Zimbabwe, Zambia, South Africa \}, \{El Salvador, Guatemala, Honduras\}, \{Indonesia, Malaysia, Singapore\}, \{Jordan, Kuwait, Saudi Arabia\}, \{Algeria, Tunisia\}, \{Colombia, Venezuela\}, \{Costa Rica, Nicaragua $\},\{$ Samoa, American Samoa $\},\{$ French Guiana, Martinique $\}$, Rwanda, Uganda $\}$ 
\{USA, Mexico, Canada, Japan, , Guam, France, Germany, Netherlands, Belgium,

Denmark, Sweden, Norway, Finland, Switzerland, Austria, Italy, Spain, Portugal, Andorra, Brazil, Argentina, Greece, Albania, Bulgaria, Serbia, Turkey\}

\{China, Taiwan, Korea, Singapore, Malaysia, Indonesia, Thailand, Myanmar, Macao, Hong Kong, Brunei, Lao, Cambodia, Vietnam, India, Philippines

\{South Africa, Malawi, Angola, Namibia, Tanzania, Zambia, Swaziland, Mozambique, Botswana, Lesotho, Zimbabwe\},

\{Russia, Ukraine, Slovakia, Hungary, Romania, Poland, Belarus, Moldova\}

\{Bolivia, Ecuador, Chile, Peru, Colombia, Venezuela, Aruba\}, \{Saudi Arabia, UAE, Kuwait, Oman, Bahrain, Qatar $\},\{$ Kazakhstan, Uzbekistan, Kyrgyzstan, Turkmenistan, Tajikistan\}, \{Congo Democ., Rwanda, Kenya, Uganda\}, \{French Guiana, Guadeloupe, Martinique\}, \{Nepal, Maldives, Sri Lanka\}, \{Cayman Islands, Jamaica $\}$, \{Barbados, Trinidad and Tobago\}, \{Santa Lucia, Guyana\}, \{Mauritius, Reunion\}, \{Egypt, Israel\}, \{Cyprus, Lebanon\}, \{Armenia, Iran\}, \{Benin, Nigeria $\},\{$ Ethiopia, Sudan $\},\{$ Vanuatu, New Caledonia \}, \{Fiji, New Zealand\}, \{Dominican Rep., Puerto Rico\}

\section{Top 3 inbound GTN}

\{USA, Mexico, Canada, UK, Puerto Rico, Bahamas, Jamaica, Dominican Rep., Spain, Cuba, France, Germany, Italy, Switzerland, Greece, Portugal, San Marino, Andorra\} \{China, Hong Kong, Taiwan, Macao, Korea, Japan, Singapore, Malaysia, Indonesia, Thailand, Myanmar, Lao, Cambodia, Vietnam, Brunei, Philippines, India \{Russia, Ukraine, Belarus, Moldova, Slovakia, Poland, Czech Republic, Turkey, Uzbekistan, Kazakhstan, Kyrgyzstan\}, \{Saudi Arabia, Kuwait, Jordan, Bahrain, Qatar, Egypt, Syria\}, \{Brazil, Argentina, Peru, Chile, Bolivia, Uruguay, Paraguay\}, \{Malawi, South Africa, Mozambique, Lesotho, Swaziland, Zimbabwe\}, \{Iran, Iraq, Armenia, Azerbaijan, Georgia\}, \{Denmark, Sweden, Norway, Finland\}, \{Australia, New Zealand, Fiji\}, \{Bulgaria, Romania, Hungary\}, \{Colombia, Venezuela, Panama\}, \{El Salvador, Guatemala, Honduras\}, \{Algeria, Libya, Tunisia\}, \{Congo Democratic, Rwanda, Uganda\}, \{Kenya, Tanzania, Zambia\}, \{Angola, Namibia\}, \{Mauritania, Nigeria\}, \{Albania, Macedonia\}, \{Costa Rica, Nicaragua\}, \{Curaçao, Netherlands\}, \{Mauritius, Reunion\}

Table 9. Clusters identified by Hierarchical Clustering Algorithm 


\begin{tabular}{|c|c|c|c|c|c|c|}
\hline \multicolumn{7}{|c|}{ Top 3 outbound GTN } \\
\hline & N. Amer. & S. Amer. & Europe & Africa & Asia & Oceania \\
\hline N. Amer. & $\begin{array}{r}71,647,048 \\
\text { (81 ties) }\end{array}$ & $\begin{array}{l}191,364 \\
\text { (15 ties) }\end{array}$ & $\begin{array}{r}4,523,794 \\
(4 \text { ties })\end{array}$ & $\begin{array}{r}12 \\
(1 \text { tie })\end{array}$ & $\begin{array}{l}1,219 \\
(1 \text { tie })\end{array}$ & $\begin{array}{r}0 \\
(0 \text { ties })\end{array}$ \\
\hline S. Amer. & $\begin{array}{r}5,210,269 \\
(20 \text { ties })\end{array}$ & $\begin{array}{r}5,091,707 \\
(26 \text { ties })\end{array}$ & $\begin{array}{r}755,216 \\
(2 \text { ties })\end{array}$ & $\begin{array}{r}0 \\
(0 \text { ties })\end{array}$ & $\begin{array}{r}0 \\
(0 \text { ties })\end{array}$ & $\begin{array}{r}0 \\
(0 \text { ties })\end{array}$ \\
\hline Europe & $\begin{array}{r}8,272,653 \\
(43 \text { ties })\end{array}$ & $\begin{array}{r}168,250 \\
(1 \text { ties })\end{array}$ & $\begin{array}{r}122,865,240 \\
(72 \text { ties })\end{array}$ & $\begin{array}{r}590 \\
(2 \text { ties) }\end{array}$ & $\begin{array}{l}187,344 \\
\text { (12 ties) }\end{array}$ & $\begin{array}{r}0 \\
(0 \text { ties })\end{array}$ \\
\hline Africa & $\begin{array}{r}469,583 \\
(40 \text { ties })\end{array}$ & $\begin{array}{r}41,745 \\
(2 \text { ties })\end{array}$ & $\begin{array}{r}2,169 \\
(2 \text { ties })\end{array}$ & $\begin{array}{r}9,796,668 \\
(99 \text { ties })\end{array}$ & $\begin{array}{r}94,418 \\
\text { (11 ties) }\end{array}$ & $\begin{array}{r}0 \\
(0 \text { ties })\end{array}$ \\
\hline Asia & $\begin{array}{r}9,361,023 \\
\quad(38 \text { ties })\end{array}$ & $\begin{array}{r}0 \\
(0 \text { ties })\end{array}$ & $\begin{array}{r}13,593,340 \\
(16 \text { ties })\end{array}$ & $\begin{array}{l}10,243 \\
(5 \text { ties })\end{array}$ & $\begin{array}{r}69,966,464 \\
(100 \text { ties })\end{array}$ & $\begin{array}{l}2,019 \\
(1 \text { tie })\end{array}$ \\
\hline Oceania & $\begin{array}{r}1,427,560 \\
(18 \text { ties })\end{array}$ & $\begin{array}{r}117 \\
(2 \text { ties })\end{array}$ & $\begin{array}{r}3 \\
(1 \text { tie })\end{array}$ & $\begin{array}{r}458 \\
\text { (4 ties) }\end{array}$ & $\begin{array}{r}2,024,146 \\
(15 \text { ties })\end{array}$ & $\begin{array}{r}135,292 \\
(8 \text { ties })\end{array}$ \\
\hline \multicolumn{7}{|c|}{ Top 3 inbound GTN } \\
\hline & N. Amer. & S. Amer. & Europe & Africa & Asia & Oceania \\
\hline N. Amer. & $\begin{array}{r}85,723,152 \\
(62 \text { ties })\end{array}$ & $\begin{array}{r}1,602,885 \\
(7 \text { ties })\end{array}$ & $\begin{array}{r}3,834,712 \\
(3 \text { ties })\end{array}$ & $\begin{array}{r}409,005 \\
(7 \text { ties })\end{array}$ & $\begin{array}{r}4,828,171 \\
(12 \text { ties })\end{array}$ & $\begin{array}{r}141,410 \\
(7 \text { ties })\end{array}$ \\
\hline S. Amer. & $\begin{array}{r}496,873 \\
(4 \text { ties })\end{array}$ & $\begin{array}{r}11,716,333 \\
(25 \text { ties })\end{array}$ & $\begin{array}{r}0 \\
(0 \text { ties })\end{array}$ & $\begin{array}{r}0 \\
(0 \text { ties })\end{array}$ & $\begin{array}{r}0 \\
(0 \text { ties })\end{array}$ & $\begin{array}{r}0 \\
(0 \text { ties })\end{array}$ \\
\hline Europe & $\begin{array}{r}6,226,678 \\
(21 \text { ties })\end{array}$ & $\begin{array}{r}344,630 \\
(3 \text { ties })\end{array}$ & $\begin{array}{r}178,514,512 \\
(51 \text { ties })\end{array}$ & $\begin{array}{r}3,802,592 \\
(31 \text { ties })\end{array}$ & $\begin{array}{r}15,787,688 \\
(10 \text { ties })\end{array}$ & $\begin{array}{r}727,939 \\
(3 \text { ties })\end{array}$ \\
\hline Africa & $\begin{array}{r}0 \\
(0 \text { ties })\end{array}$ & $\begin{array}{r}0 \\
(0 \text { ties })\end{array}$ & $\begin{array}{r}0 \\
(0 \text { ties })\end{array}$ & $\begin{array}{r}19,879,252 \\
(42 \text { ties })\end{array}$ & $\begin{array}{r}2,446,536 \\
(2 \text { ties })\end{array}$ & $\begin{array}{r}0 \\
(0 \text { ties })\end{array}$ \\
\hline Asia & $\begin{array}{r}502,112 \\
(2 \text { ties })\end{array}$ & $\begin{array}{r}0 \\
(0 \text { ties })\end{array}$ & $\begin{array}{r}13,622,830 \\
(7 \text { ties })\end{array}$ & $\begin{array}{r}2,503,733 \\
(7 \text { ties })\end{array}$ & $\begin{array}{r}292,440,864 \\
(100 \text { ties })\end{array}$ & $\begin{array}{r}750,694 \\
(6 \text { ties })\end{array}$ \\
\hline Oceania & $\begin{array}{r}0 \\
(0 \text { ties })\end{array}$ & $\begin{array}{r}0 \\
(0 \text { ties })\end{array}$ & $\begin{array}{r}0 \\
(0 \text { ties })\end{array}$ & $\begin{array}{r}22,870 \\
(1 \text { ties })\end{array}$ & $\begin{array}{r}1,081,600 \\
(2 \text { ties })\end{array}$ & $\begin{array}{r}1,986,949 \\
(20 \text { ties })\end{array}$ \\
\hline
\end{tabular}

Table 10. Cross-regional distribution of tourism flows 


\begin{tabular}{|c|c|c|c|c|c|c|c|}
\hline Triad code & Triad pattern & Top 1 outbound & Top 2 outbound & Top 3 outbound & Top 1 inbound & Top 2 inbound & Top 3 inbound \\
\hline 3 & $\mathrm{~A}, \mathrm{~B}, \mathrm{C}$ & $1,591,802$ & $1,552,064$ & $1,518,520$ & $1,581,932$ & $1,555,556$ & $1,531,906$ \\
\hline 102 & $\mathrm{~A}<->\mathrm{B}, \mathrm{C}$ & 955 & 1,771 & 3,802 & 2,066 & 4,845 & 8,819 \\
\hline $021 \mathrm{C}$ & $\mathrm{A}->\mathrm{B}->\mathrm{C}$ & 92 & 341 & 573 & 53 & 152 & 270 \\
\hline $111 \mathrm{D}$ & $\mathrm{A}<->\mathrm{B}<-\mathrm{C}$ & 110 & 301 & 724 & 0 & 21 & 47 \\
\hline $111 \mathrm{U}$ & $\mathrm{A}<->\mathrm{B}->\mathrm{C}$ & 0 & 7 & 23 & 54 & 185 & 323 \\
\hline 201 & $A<->B<->C$ & 0 & 3 & 3 & 0 & 7 & 14 \\
\hline 120D & $A<-B->C, A<->C$ & $\mathbf{0}$ & 40 & 94 & $\mathbf{0}$ & 1 & 13 \\
\hline $120 U$ & $A->B<-C, A<->C$ & $\mathbf{0}$ & 1 & 11 & $\mathbf{0}$ & 14 & 52 \\
\hline $120 \mathrm{C}$ & $\mathrm{A}->\mathrm{B}->\mathrm{C}, \mathrm{A}<->\mathrm{C}$ & 0 & 2 & 4 & 0 & 4 & 4 \\
\hline 210 & $\mathrm{~A}->\mathrm{B}<->\mathrm{C}, \mathrm{A}<->\mathrm{C}$ & 0 & 1 & 11 & 0 & 2 & 18 \\
\hline 300 & $A<->B<->C, A<->C$ & $\mathbf{0}$ & $\mathbf{0}$ & $\mathbf{0}$ & $\mathbf{0}$ & $\mathbf{0}$ & 2 \\
\hline
\end{tabular}

Table 11. GTN triad census (transitive triads in bold) 


\begin{tabular}{|c|c|c|c|c|}
\hline Motif Id & Top 2 outbound & Top 3 outbound & Top 2 inbound & Top 3 inbound \\
\hline \multirow{3}{*}{$\begin{array}{l}38 \\
\text { Feed- } \\
\text { forward } \\
\text { loop }\end{array}$} & $C=10.6 ; Z=4.21^{*}$ & $\mathrm{C}=16.1 ; \mathrm{Z}=3.41^{*}$ & $\mathrm{C}=13.18 ; \mathrm{Z}=4.73^{*}$ & $\mathrm{C}=20.69 ; \mathrm{Z}=5.66^{*}$ \\
\hline & Venezuela & Canada & China & UK \\
\hline & Colombia $\searrow$ USA & Mexico $\otimes_{\text {France }}$ & Thailand ${ }^{\infty}$ Myanmar & Canada \\
\hline \multirow[b]{2}{*}{$\begin{array}{l}46 \\
\text { Uplinked } \\
\text { mutual } \\
\text { dyad }\end{array}$} & - & - & $\mathrm{C}=7.10 ; \mathrm{Z}=7.06^{*}$ & $\mathrm{C}=12.8 ; \mathrm{Z}=10.38^{*}$ \\
\hline & & - & USA $\diamond \gg$ Bahamas & $\$$ Guam \\
\hline \multirow[b]{2}{*}{$\begin{array}{l}102 \\
\text { One } \\
\text { mutual } \\
\text { dyad }\end{array}$} & - & - & $\mathrm{C}=2.02 ; \mathrm{Z}=5.31^{*}$ & - \\
\hline & - & - & Russia F. & - \\
\hline \multirow[b]{2}{*}{$\begin{array}{l}108 \\
\text { One } \\
\text { mutual } \\
\text { dyad }\end{array}$} & $\mathrm{C}=5.1 ; \mathrm{Z}=7.19^{*}$ & $C=5.5 ; Z=4.15^{*}$ & - & $\mathrm{C}=3.2 ; \mathrm{Z}=5.8^{*}$ \\
\hline & Algeria $\diamond \bigotimes_{\text {Canada }}$ & Greece & - & Turkey $\bigotimes_{\text {Georgia }}$ \\
\hline \multirow[b]{2}{*}{$\begin{array}{l}110 \\
\text { Feedback } \\
\text { with two } \\
\text { mutual } \\
\text { dyads }\end{array}$} & - & $\mathrm{C}=0.65 ; \mathrm{Z}=7.20^{*}$ & - & $\mathrm{C}=4.4 ; \mathrm{Z}=15.09^{*}$ \\
\hline & - & Indonesia & - & Hong Kong \\
\hline
\end{tabular}

Table 12. Three-node motifs in the top k outbound and inbound GTN 


\begin{tabular}{|c|c|c|c|c|}
\hline $\begin{array}{l}\text { Motif } \\
\text { Id }\end{array}$ & Top 2 outbound & Top 3 outbound & Top 2 inbound & Top 3 inbound \\
\hline \multirow[b]{2}{*}{344} & $\mathrm{C}=0.11 ; \mathrm{Z}=3.99^{*}$ & $\mathrm{C}=0.14 ; \mathrm{Z}=6.68^{*}$ & - & - \\
\hline & Ireland Andorra & $\begin{array}{l}\text { Malaysia Seychelles } \\
\text { Mauritius Hong Kong }\end{array}$ & - & - \\
\hline \multirow[b]{2}{*}{2186} & $\mathrm{C}=23.95 ; \mathrm{Z}=2.64^{*}$ & - & - & - \\
\hline & Venezuela Colombia & - & - & - \\
\hline \multirow[b]{2}{*}{4440} & $\mathrm{C}=0.56 ; \mathrm{Z}=2.67^{*}$ & - & - & - \\
\hline & $\begin{array}{l}\text { South Afr. Uganda } \\
\text { Ethiopia Botswana }\end{array}$ & - & - & - \\
\hline \multirow[b]{2}{*}{$\begin{array}{l}6552 \\
\mathrm{Bi}- \\
\text { fan }\end{array}$} & $\mathrm{C}=0.70 ; \mathrm{Z}=5.57^{*}$ & - & - & - \\
\hline & Spain Austria & - & - & - \\
\hline \multirow[b]{2}{*}{906} & - & $\mathrm{C}=0.02 ; \mathrm{Z}=4.44$ & - & - \\
\hline & - & Uzbekistan Ukraine & - & - \\
\hline \multirow[b]{2}{*}{4694} & - & $\mathrm{C}=0.10 ; \mathrm{Z}=6.29^{*}$ & - & - \\
\hline & - & $\begin{array}{l}\text { Malaysia Thailand } \\
\text { Hong Kong Afghanistan }\end{array}$ & & - \\
\hline \multirow[b]{2}{*}{5018} & - & $\mathrm{C}=0.12 ; \mathrm{Z}=0.12^{*}$ & - & - \\
\hline & - & Albania France & & - \\
\hline \multirow[b]{2}{*}{94} & - & - & $\mathrm{C}=15.27 ; \mathrm{Z}=3.72^{*}$ & $\mathrm{C}=31.80 ; \mathrm{Z}=6.51^{*}$ \\
\hline & - & - & $\begin{array}{l}\text { USA Canada } \\
\text { Dom. Rep Amer.Samoa }\end{array}$ & USA Canada \\
\hline \multirow[b]{2}{*}{408} & - & - & $\mathrm{C}=0.70 ; \mathrm{Z}=5.08^{*}$ & $\mathrm{C}=1.04 ; \mathrm{Z}=3.97^{*}$ \\
\hline & & & $\begin{array}{c}\text { Philippines USA } \\
\text { Korea Micronesia }\end{array}$ & $\begin{array}{c}\text { Indonesia Malaysia } \\
\text { Australia Brunei Dar. }\end{array}$ \\
\hline
\end{tabular}




\begin{tabular}{|c|c|c|c|c|}
\hline \multirow[b]{2}{*}{350} & - & - & - & $\mathrm{C}=1.73 ; \mathrm{Z}=5.83^{*}$ \\
\hline & - & - & - & $\begin{array}{lll}\text { Ukraine Russia } \mathrm{F} . \\
\text { Moldova Poland }\end{array}$ \\
\hline \multirow[b]{2}{*}{394} & - & - & - & $\mathrm{C}=0.53 ; \mathrm{Z}=3.99 *$ \\
\hline & - & - & - & Saudi Arab. Bahrain \\
\hline \multirow[b]{2}{*}{414} & - & - & - & $\mathrm{C}=0.81: \mathrm{Z}=3.30^{*}$ \\
\hline & - & - & - & $\begin{array}{cc}\text { USA UK } \\
\text { Mexico Tanzania }\end{array}$ \\
\hline
\end{tabular}

Notes: C: Concentration (per thousand); Z: Z score; (*): p-value $\leq 0.01$; Random networks: 1,000

Table 13. Four-node motifs in the top k outbound and inbound GTN 


\begin{tabular}{|c|c|c|c|c|c|c|}
\hline ERGM term & Top 1 outbound & Top 2 outbound & Top 3 outbound & Top 1 inbound & Top 2 inbound & Top 3 inbound \\
\hline Edges & $-2.43(0.04)^{*}$ & $-4.50(7.89 \mathrm{e}-02)^{*}$ & $-2.98(3.06 \mathrm{e}-01)^{*}$ & $-4.49(0.07)^{*}$ & $-5.55(0.18)^{*}$ & $-4.49(5.53 \mathrm{e}-02)^{*}$ \\
\hline Istar-2 & $0.02(4.8 \mathrm{e}-04)^{*}$ & $7.25(3.56 \mathrm{e}-03)^{*}$ & $-9.16 \mathrm{e}-02(1.16 \mathrm{e}-0.2)^{*}$ & - & \\
\hline Istar-3 & - & $-5.69(5.56 \mathrm{e}-05)^{*}$ & $3.32 \mathrm{e}-03(5.45 \mathrm{e}-04)^{*}$ & - & \\
\hline Istar-4 & - & - & $-3.55 \mathrm{e}-05(8.32 \mathrm{e}-06)^{*}$ & - & \\
\hline Ostar-2 & - & - & - & $0.04(1.4 \mathrm{e}-03)^{*}$ & $0.36(0.01)^{*}$ & \\
\hline Ostar-3 & - & - & - & $-0.014(4.2 \mathrm{e}-04)^{*}$ & $7.32 \mathrm{e}-03(3.78 \mathrm{e}-04)^{*}$ \\
\hline Ostar-4 & - & - & - & - & $-2.76 \mathrm{e}-04(1.91)^{*}$ \\
\hline Gwidegree & $-3.48(0.29)^{*}$ & $-1.25(1.01 \mathrm{e}-01)^{*}$ & $-4.44(1.25) *$ & - & - \\
\hline Gwidegree.decay & $2.19(0.02)^{*}$ & $-1.59(6.39 \mathrm{e}-03)^{*}$ & $0.7(5.43 \mathrm{e}-01)^{*}$ & - & - & - \\
\hline Gwodegree & - & - & - & $-1.33(0.37)^{*}$ & $-0.24(0.07)^{*}$ & $-6.91(7.40 \mathrm{e}-02)^{*}$ \\
\hline Gwodegree.decay & - & - & - & $2.12(0.07)^{*}$ & $2.18(0.28)^{*}$ & $1.82(8.10 \mathrm{e}-03)^{*}$ \\
\hline AIC & 504.7 & 3,681 & 5,517 & 1,424 & 3,362 & 3,405 \\
\hline BIC & 539.7 & 3,725 & 5,570 & 1,459 & 4,362 \\
\hline
\end{tabular}

Notes: Estimate (Std. Error); $\quad *$ : p-value $\leq 0.01$ (two-tailed tests).

Table 14. ERGM fit for the top k outbound and inbound GTN (Monte Carlo ML method) 


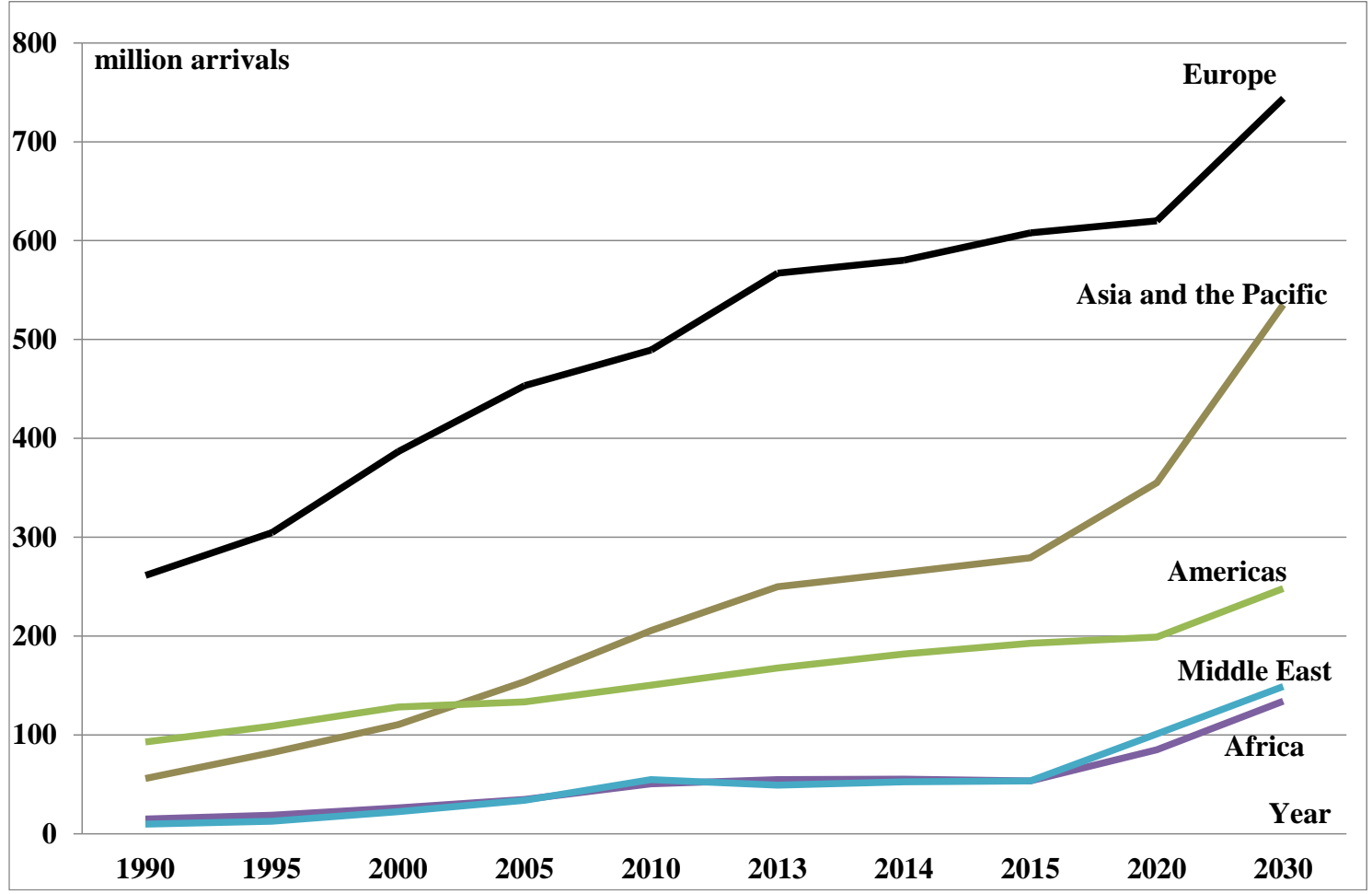

Figure 1. International tourist arrivals by destination region (past data and projections) 


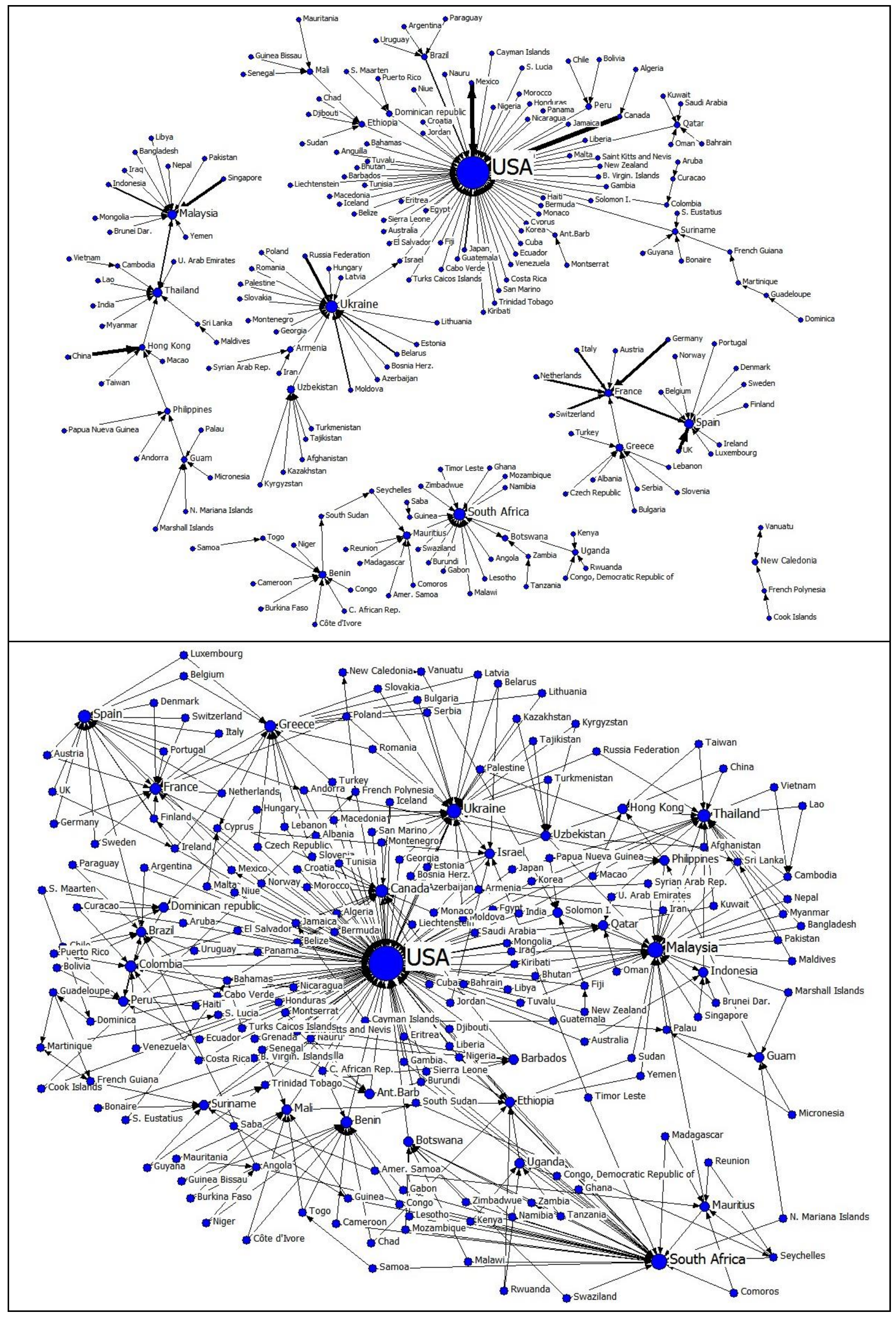




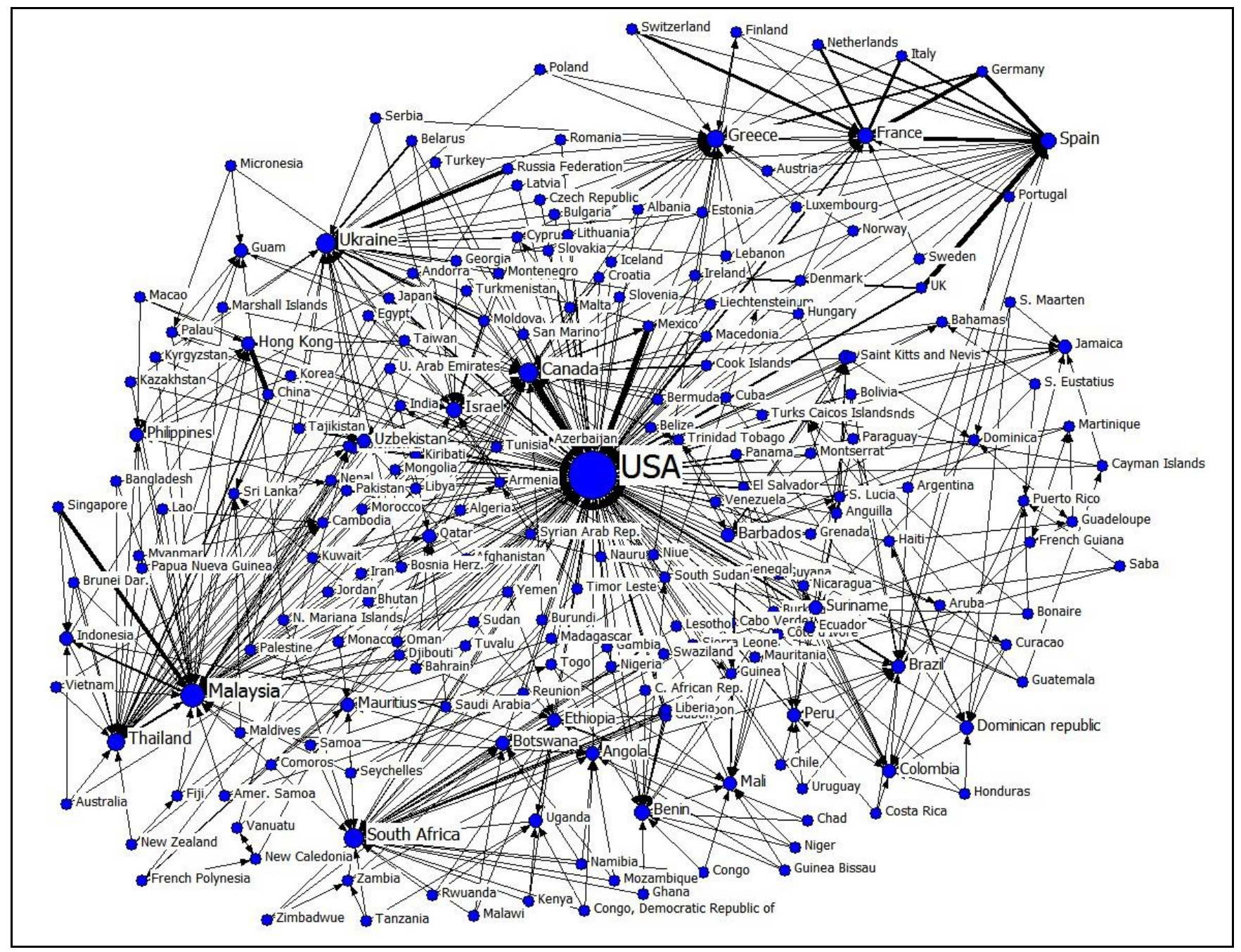

Figure 2. Top 1, 2 and 3 outbound GTN 


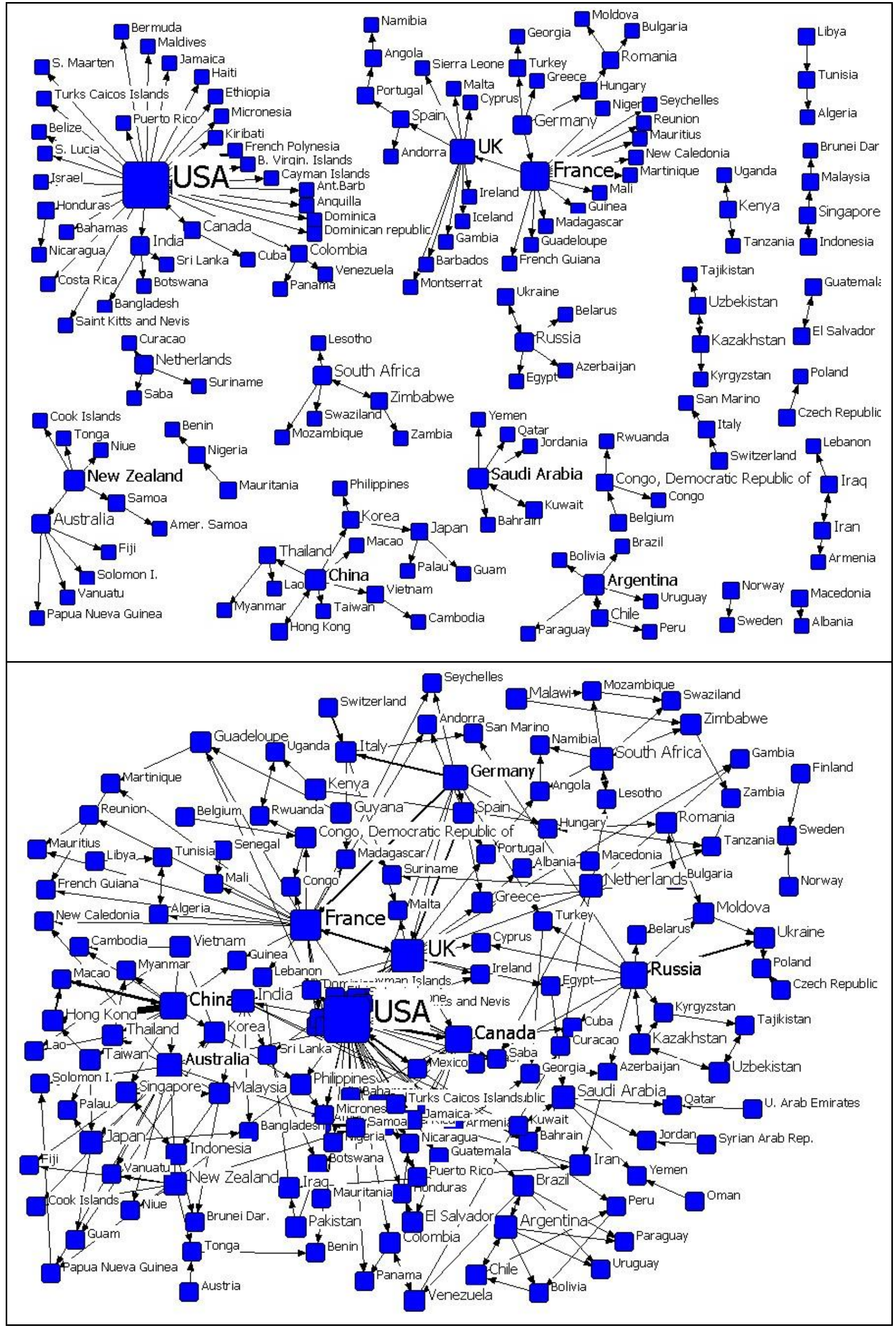




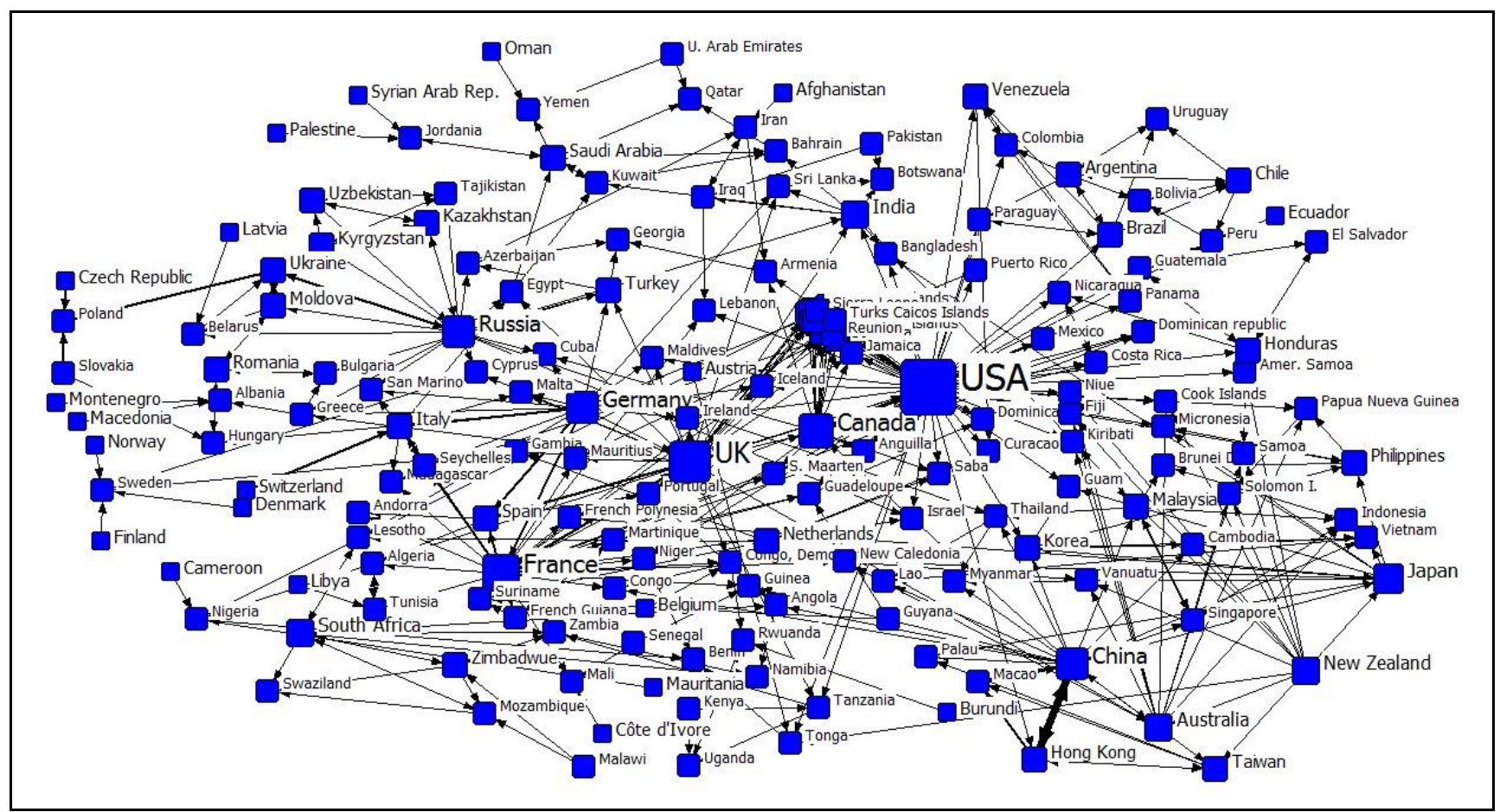

Figure 3. Top 1, 2 and 3 inbound GTN 